\title{
Research
}

\section{How Multilevel Societal Learning Processes Facilitate Transformative Change: A Comparative Case Study Analysis on Flood Management}

\author{
Claudia Pahl-Wostl ${ }^{1}$, Gert Becker ${ }^{2}$, Christian Knieper $^{1}$ and Jan Sendzimir $^{3}$
}

\begin{abstract}
Sustainable resources management requires a major transformation of existing resource governance and management systems. These have evolved over a long time under an unsustainable management paradigm, e.g., the transformation from the traditionally prevailing technocratic flood protection toward the holistic integrated flood management approach. We analyzed such transformative changes using three case studies in Europe with a long history of severe flooding: the Hungarian Tisza and the German and Dutch Rhine. A framework based on societal learning and on an evolutionary understanding of societal change was applied to identify drivers and barriers for change. Results confirmed the importance of informal learning and actor networks and their connection to formal policy processes. Enhancing a society's capacity to adapt is a long-term process that evolves over decades, and in this case, was punctuated by disastrous flood events that promoted windows of opportunity for change.
\end{abstract}

Key Words: adaptive management; comparative analysis; integrated flood protection; Rhine; societal learning; Tisza; transformative change; water governance

\section{INTRODUCTION}

The management of environmental resources has traditionally focused on narrow objectives and on taming the vagaries of nature to ensure human well-being. A case in point is dealing with natural hazards such as floods and droughts. Large-scale infrastructure construction converted dry regions to agricultural gardens and swampy floodplains to flourishing towns. However, in the long run such practices have proven to be unsustainable. Increasing human water security by technical infrastructure development has led to increasingly unsustainable trade-offs between human and environmental water needs (Vörösmarty et al. 2010, Pahl-Wostl et al. 2012). Ecosystems have been degraded, and the services they provide are in decline. At the same time, protected areas have become more vulnerable to climate extremes, which are expected to increase because of climate change (Bates et al. 2008). The risk of damages and fatalities increases when climate extremes cross boundaries of protection and intensive land use expands into areas frequently exposed to disturbance. Hence, a reconsideration of management paradigms toward integrated, adaptive, and collaborative approaches has started over the past decade and has been strongly reinforced by the prospect of climate change impacts (Berkes et al. 2002, Gleick 2003, Pahl-Wostl 2007a, b, Palmer et al. 2008, Pahl-Wostl et al. 2011).

Changes in a management paradigm and associated system transformations require time. Historical investments and institutional path dependencies have generated an interdependence of system elements, e.g., institutional design, technical infrastructure, knowledge, and distribution of power, that guarantee the functioning of a system and the convergence of expectations of actors (Geels 2002, Smith et al. 2005, PahlWostl 2007a, Pahl-Wostl et al. 2011). The downside of such interdependence is that it often prevents change and generates a selective environment, thus excluding innovative but noncompatible approaches.

Recognizing the importance of a profound system transformation for sustainable development, various strands of scholarship have developed to analyze drivers and barriers for change and how system transformation can be facilitated. One stream of research focuses on an improved understanding of the requirements for adaptive resource governance in socialecological systems (Dietz et al. 2003, Folke et al. 2005, PahlWostl 2009). Folke et al. (2005) point out that adaptive governance systems often self-organize as social networks with teams and actor groups that draw on various knowledge systems and experiences for the development of both a common understanding and policies. Empirical evidence has shown that the formation of informal actor networks plays an important role in the early phase of change (Nooteboom 2006, Olsson et al. 2006). Ostrom (2001) highlighted the importance of polycentricity for adaptive governance, which was confirmed in a comprehensive comparative analysis of water governance systems by Pahl-Wostl et al. (2012). Polycentric systems are assumed to enhance innovation, learning, adaptation, trustworthiness, level of cooperation among participants, and the achievement of more effective, equitable, and sustainable outcomes at multiple scales (Ostrom 2010). Armitage (2008) established links to political ecology addressing the importance of power, scale and levels of organization, knowledge valuation, the positioning of social actors, and social constructions of nature, which might explain

\footnotetext{
${ }^{1}$ Institute of Environmental Systems Research, University of Osnabrück, ${ }^{2}$ Institute for Environmental Studies, VU University Amsterdam, ${ }^{3}$ International Institute for Applied Systems Analysis
} 
certain barriers to change and learning. Another stream of research, the transition management literature, draws on complex systems with an evolutionary approach and focuses on socio-technical systems. A prescriptive model has been developed that identifies different phases at different system levels including goal setting, experimentation with innovative approaches, societal learning, and finally, institutionalization (Rotmans et al. 2001, Loorbach 2007). A key element of transition management is the design of largely informal transition arenas with strong leadership by small groups of innovators.

In their thoughtful review of these two strands of scholarship, Smith and Sterling (2010) highlighted the critical importance of the political dimensions in managing system transformations. They identified, as critical issues, the question of who governs and who determines the framing of sustainability issues. This implies that research needs to devote more attention to how informal settings promoted by scholars in adaptive governance and transition management are linked to clearly delineated jurisdictions and embedded in formal multilevel governance systems (Smith and Sterling 2010). As Pahl-Wostl (2009) emphasized, understanding such links is also essential to move from discourse on the need for change, to structural change in regulatory frameworks and management practices. Informal settings provide space for experimentation, which can lead to the revision of assumptions and paradigms, i.e., reframing, whereas formal policy processes are required to secure the outcomes of learning and develop binding commitment.

We contribute to closing the knowledge gaps identified. We focused, in particular, on what are considered essential elements supporting transformative change: (1) the link between largely informal learning cycles and formal policy processes; and (2) the vertical coordination of governance levels to capture the role of different kinds of activities at various levels with bottom-up and top-down processes. This focus was used in an analysis of three case studies with a long history of severe flooding, the Hungarian Tisza, as well as the German and Dutch Rhine basins, to examine the changes in flood management.

\section{CONCEPTUAL AND METHODOLOGICAL FRAMEWORK TO ANALYZE TRANSFORMATIVE CHANGE}

\section{Conceptual framework for the analysis of transformative change}

Pahl-Wostl (2009) developed a conceptual framework to analyze how multilevel and multiloop learning processes influence the dynamics of factors underlying the adaptive capacity of resource governance and management systems. Adaptive capacity was defined by Pahl-Wostl (2009) as the ability of resource governance and management systems to first alter processes, i.e., adaptation, and if required convert structural elements, i.e., transformation, as a response to experienced or expected changes in the societal or natural environment. In this definition, adaptive capacity embraces transformative capacity. The conceptual framework captures different stages of societal learning by further developing the triple-loop learning concept to describe and analyze different stages of learning, ranging from incremental learning, i.e., single loop, to structural change, i.e, triple loop. The concept of triple-loop learning, which is a refinement of the concept of double-loop learning, has become quite popular in management theory to guide the concept and the practice of managing change in organizations (Argyris and Schön 1978; Hargrove 2002). As well, it has proven a promising approach to conceptualize societal learning (Armitage et al. 2008, PahlWostl 2009).

Single-loop learning refers to an incremental improvement of action strategies without questioning the underlying assumptions. Double-loop learning refers to a revisiting of assumptions, e.g., about cause-effect relationships, within a value-normative framework. In triple-loop learning, one begins to reconsider underlying values and beliefs and worldviews, if assumptions within a worldview do not hold any more. Pahl-Wostl (2009) identified a number of change elements that are key to such processes, including institutions, actor networks, multilevel interactions across administrative boundaries, and vertical integration. The triple-loop learning concept can distinguish between adaptation and transformation. Adaptation occurs within a value-normative framework and refers thus to single or partly double-loop learning, whereas transformation implies structural change and must thus embrace triple-loop learning. Fig. 1 depicts what such understanding might imply for the relationship between formal policy cycles and largely informal processes supporting double- or triple-loop learning.

Adaptive change remains largely within the reigning paradigm and structural context set by the formal policy process. This implies that learning influences implementation and monitoring as well as the development of operational goals and measures within given structural constraints without feedback to effect structural change. Transformative change and triple-loop learning extend to influence those phases of a policy cycle in which problems are framed, strategic goals are set, and policy is formulated. Such learning also interacts with the phases of developing operational goals and measures as well as implementation and monitoring of effectiveness. This analytical distinction may be blurred in reality, because double-loop learning also includes a reinterpretation of existing institutions (Pahl-Wostl 2009). Multiloop learning is an iterative and recursive process across levels and phases of the policy cycle. A key assumption for Figure 1 is that higher levels of learning require informal settings, but are only 
Fig. 1. Schematic representation of links between formal policy and informal learning cycles. The policy cycle is depicted in three aggregated phases. Bold arrows denote links between learning and policy cycles. Within the formal policy cycle, learning refers mainly to single-loop learning, the incremental improvement of established routines. Informal settings are required to refer to higher levels of learning. Adaptive learning refers mainly to the operational implementation and monitoring phases, to single- or partly double-loop learning, i.e., start of reframing, that does not yet change the reigning paradigm and the whole structural context settings, e.g., institutions, technical infrastructure. Transformative learning implies change in strategic goals and policy formulation, which means triple-loop learning and change in the reigning paradigm, in regulatory frameworks, and prevailing codified practices, e.g., technical design principles. In the long term, such change has an influence on operational goals and measures, on implementation, and monitoring. The simplified figure should be seen as a kind of projection of a threedimensional spiral in time on a two-dimensional space and includes major pathways of interaction.

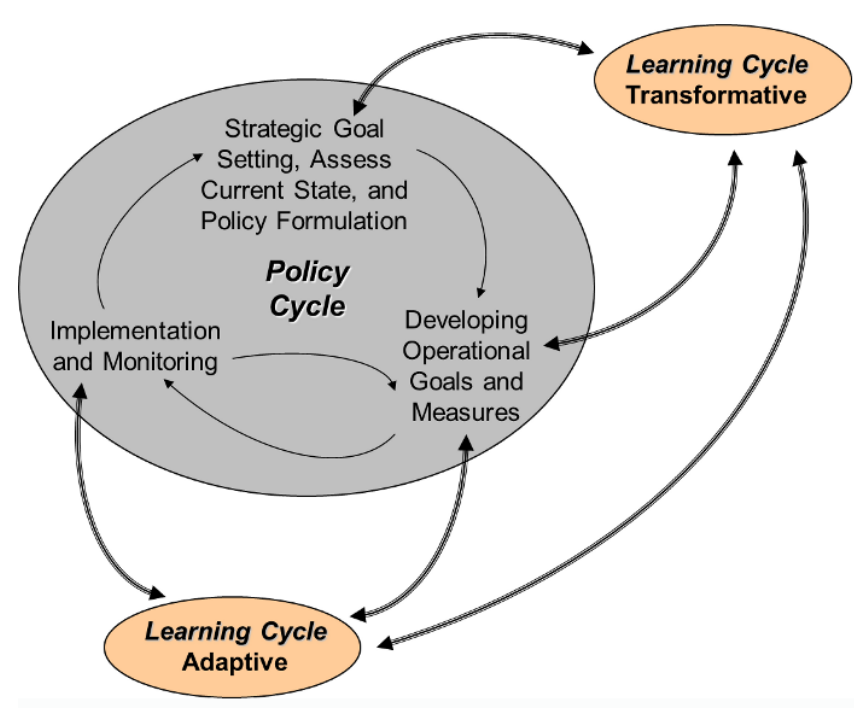

effective, i.e., leading from reframing to transformation, if connected to formal processes (Pahl-Wostl 2009).

\section{Methodological framework and operational characterization}

To develop an operational characterization of the evolution of a new management approach in case studies over time, the management and transition framework (MTF) has been used. The MTF allows a coherent representation of multilevel water governance and management systems and supports structured analyses by the provision of standardized definitions of variables, e.g., actors, institutions, and their relationships (Knieper et al. 2010, Pahl-Wostl et al. 2010). An important variable is the action situation (AS), which represents a structured social interaction context. Elinor Ostrom initially introduced the notion of an AS as a core concept of the institutional analysis and development framework to depict a collective choice situation in a common pool resource game (Ostrom 2005). The notion of an AS was further developed and broadened for application in the MTF (Knieper et al. 2010, Pahl-Wostl et al. 2010). We used action situations at a much higher level of aggregation of social processes in the context of water management. At such a level of aggregation, the focus was not on the microdynamics within the AS but on the outcomes produced in ASs that, in turn, influence other ASs. Influence might, for example, imply that knowledge is generated as outcome of one AS and has effects in another AS. In this way, a management context is represented as a network of ASs connected through their outcomes. Processes within an AS are analyzed only in a qualitative manner, e.g., the roles of various actors and the nature of participation of different actor groups.

The MTF makes an analytical distinction between formal policy processes and largely informal learning processes. An AS is either part of a formal policy process or an informal learning process. An AS is considered to be part of a largely informal learning process if social interactions are not predominantly shaped by formal regulations, most participating actors have no formal mandate, and outcomes are not formally binding. The MTF predefines phases for both policy and learning processes. For the policy processes, these phases include: strategic goal setting, assessment of current state, policy formation, developing operational goals, developing measures, implementation, and monitoring. Phases in learning processes include: problem structuring and reframing, development of action plans and mobilization of additional support, and implementation and evaluation of pilots/experiments. Each AS operates at a particular spatial level, e.g., local, national, or river basin. Each AS produces an outcome, which can refer to changes in institutions, knowledge, and operational outcomes. An AS could, for example, refer to the development of a regional plan for the implementation of flood management measures. The lead within this AS is with a regional authority. Stakeholders from the same, e.g., regional farmer associations, and lower, e.g., municipalities, levels are involved in the process. This AS is influenced by national legislation. It is also influenced by knowledge generated in a local pilot project on floodplain restoration. As shown in Figure 2, empirical results derived from case study data can be depicted as networks of connected ASs. These diagrams do not constitute a chronological representation. They provide a compressed view along the dimension of time and show which kind of ASs and links have been identified. 
Table 1. Characteristics of governance systems and expected influence on transformative change.

\begin{tabular}{|c|c|c|}
\hline Characteristic & $\begin{array}{c}\text { Management and transition framework (MTF) based } \\
\text { representation }\end{array}$ & $\begin{array}{l}\text { Influence on transformative change (Pahl-Wostl 2009, } \\
\text { Pahl-Wostl et al. 2012) }\end{array}$ \\
\hline $\begin{array}{l}\text { Link between formal } \\
\text { and informal processes }\end{array}$ & $\begin{array}{l}\text { Linkages between formal policy and informal learning } \\
\text { processes and degree of subsequent influence of learning } \\
\text { on the policy process through: (1) flow of knowledge } \\
\text { from informal to formal processes, i.e., knowledge } \\
\text { generation in informal platforms and integration in } \\
\text { formal management; and (2) bridging organizations or } \\
\text { individuals, e.g., social entrepreneurs, who participate in } \\
\text { both formal and informal processes. }\end{array}$ & $\begin{array}{l}\text { Higher levels of learning require informal settings but } \\
\text { are only effective, i.e., leading from reframing to } \\
\text { transformation, if connected to formal processes (Fig. } \\
\text { 1). }\end{array}$ \\
\hline $\begin{array}{l}\text { Degree of } \\
\text { centralization }\end{array}$ & $\begin{array}{l}\text { The multilevel governance structure is characterized by } \\
\text { the kind of activities, i.e., phases in the policy cycle and } \\
\text { in learning processes, that occur at different spatial } \\
\text { levels. Centralization is high if strategic goals and policy } \\
\text { are only formulated at the national level, and regional } \\
\text { levels implement according to orders from the top. } \\
\text { Actors from the national level have the lead role in most } \\
\text { action situations (AS), even at lower levels. }\end{array}$ & $\begin{array}{l}\text { Centralized regimes have lower adaptive and } \\
\text { transformative capacity than polycentric systems, } \\
\text { which are characterized by a decentralization of power } \\
\text { combined with effective coordination and a balance } \\
\text { between bottom-up and top-down processes. }\end{array}$ \\
\hline Vertical coordination & $\begin{array}{l}\text { Linkages between spatial levels, i.e., institutions, } \\
\text { knowledge, and operational outcomes are generated in } \\
\text { an action situation (AS) at a certain spatial level and } \\
\text { influence an AS located at another level; actors } \\
\text { operating at more than one level; degree of participation } \\
\text { of actors between levels, e.g., actors from regional levels } \\
\text { participate in AS at national level; and top-down policy } \\
\text { trajectories and bottom-up processes influencing higher } \\
\text { level policies. }\end{array}$ & $\begin{array}{l}\text { Effective vertical coordination with regard to the } \\
\text { involvement of actors from different levels in policy } \\
\text { development and implementation, and with regard to } \\
\text { knowledge integration is essential for high adaptive } \\
\text { and transformative capacity. }\end{array}$ \\
\hline
\end{tabular}

As summarized in Table 1, this representation characterizes the links between formal policy and informal learning processes, the feedbacks between phases, vertical coordination across levels, and the relative importance of topdown and bottom-up pathways of influence and degree of centralization. Table 1 lists as well the expected influence of regime characteristics on transformative change.

Figure A1 lists the definitions of all terms used in the MTF analyses. More details on the conceptual and methodological foundations are given by Pahl-Wostl et al. (2010) and Knieper et al. (2010).

\section{CASE STUDIES AND DATA COLLECTION}

\section{Changes in flood management paradigm}

We applied the MTF to analyze changes in the paradigm underlying flood policy and the influence of learning processes over the past decades in three case studies with a long history of severe flooding: the Hungarian Tisza and the German and Dutch Rhine basins. All basins are characterized by major reconfigurations of the river and floodplain morphology through engineering to optimize navigation and technical flood control. The three case study countries differ both in political setting and history, the role of government, and the role of informal networks in policy processes. In the flood management domain, one can observe a paradigm shift, at least as far as discourse is concerned, from flood control by technical measures to integrated flood(plain) management based on an integrated landscape approach (Oppermann et al. 2009, Smith and Barchiesi 2009, WMO 2009, Sendzimir et al. 2010). Traditional flood management largely focuses on keeping the water out of the landscape by using structural measures, such as dikes or reservoirs. It is a reactive approach that protects human lives and assets exposed to increasing flood risk because the settlements are on the former river floodplains. In the middle of the past century, the influential work of the geographer White highlighted the shortcomings of an overreliance on technical infrastructure (White 1945). In recent decades, one could note a slow progression toward more integrated approaches in flood management practice, such as moving from dike construction to increasing the storage of runoff in renaturalized or artificial wetlands or acknowledging the need for risk prevention approaches in land use policies (Moss and Monstadt 2008). However, flood management practice is far from adopting a fully integrated paradigm, which is assumed to be required to ensure effective, efficient, and sustainable flood management, in particular in times of climate change (WMO 2009). An integrated flood management paradigm argues that instead of destroying natural capital, preserving and/or restoring natural 
Table 2. Data collected in the case studies.

\begin{tabular}{|c|c|c|c|}
\hline Variable & Attributes & Relations & Examples from Dutch Rhine case study \\
\hline $\begin{array}{l}\text { Action Situation } \\
\text { (AS) }\end{array}$ & $\begin{array}{l}\text { Spatial Unit, } \\
\text { Phase (policy } \\
\text { or learning } \\
\text { process) }\end{array}$ & $\begin{array}{l}\text { Influenced by institution } 1 \text {, } \\
\text { knowledge } 1 \text {, operational } \\
\text { outcome } 1 \text {; } \\
\text { Produces institution } 2 \text {, } \\
\text { knowledge } 2 \text {, operational } \\
\text { outcome } 2\end{array}$ & $\begin{array}{l}\text { AS "Early 1970s - 1976: Change Scheldt Estuary Plan" } \\
\text {-Spatial Unit: The province of Zeeland } \\
\text {-Administrative Level: Regional } \\
\text {-Phase: Implementation (policy process) } \\
\text { •Influenced: by institution "Delta Act" (formal) and "international } \\
\text { environmental values (informal societal norm), by knowledge } \\
\text { "knowledge on closing estuaries", by operational outcomes "opposition } \\
\text { to Scheldt Estuary closure" and "Deltawerken" } \\
\text { •Produces: institution "new Scheldt plan", knowledge "ecosystem based } \\
\text { management" and "ecological value of the Scheldt Basin", operational } \\
\text { outcome "innovative dam construction in Scheldt Estuary" }\end{array}$ \\
\hline
\end{tabular}

\begin{tabular}{|c|c|c|c|}
\hline Actor & $\begin{array}{l}\text { Individual or } \\
\text { collective }\end{array}$ & $\begin{array}{l}\text { Participates in AS in a } \\
\text { certain role (lead, active, or } \\
\text { passive) }\end{array}$ & $\begin{array}{l}\text { Actor 'Rijkswaterstaat' } \\
\text { •Collective actor } \\
\text {-Lead role in eight ASs and active participant in nine ASs }\end{array}$ \\
\hline
\end{tabular}

$\begin{array}{lll}\text { Institution } & \begin{array}{l}\text { Legal } \\ \text { formality }\end{array} & \begin{array}{l}\text { Is produced by AS 1; } \\ \text { Influences AS } 2\end{array}\end{array}$

Institution "Flood Action Plan Rhine"

-Legal formality: informal, but documented

-Produced by AS “1998: international coordination Rhine flood protection"

-Influences AS “2000: development of Room for River Programme draft"

Knowledge

Operational

Outcome
Is produced by AS 1; Influences AS 2
Knowledge "ecosystem based management"

-Produced by AS "early 1970s - 1976: change Scheldt Estuary plan" -Influences AS “1984: develop guidance for Water Policy II" and "1986-1992: develop alternative approaches to flood management"

Operational Outcome "opposition to Scheldt Estuary closure" -Produced by AS "early 1970s: oppose Scheldt Estuary plan" -Influences AS "early 1970s - 1976: change Scheldt Estuary plan" infrastructure is required to build adaptive capacity and reduce vulnerability to climate change impacts (Oppermann et al. 2009, Smith and Barchiesi 2009, WMO 2009). Our analyses focused on the following elements (WMO 2009) to identify if and to which extent a shift toward an integrated flood management paradigm has occurred: adoption of an ecosystem approach taking ecological services into account, e.g., increased buffering capacity of landscape by floodplain restoration; ensure a participatory approach, e.g., include stakeholders in policy development and implementation; and innovative ways of managing risks and uncertainties, e.g., adoption of a mix of strategies, i.e.,robust planning. Our analyses identified the role of the characteristics listed in Table 1 to support such changes.

\section{Data collection}

Table 2 provides an overview on the data collected in each case study. Data collection was guided by standardized, MTFbased protocols with operational definitions for each variable (Knieper et al. 2010). It builds on considerable expertise and empirical analyses developed in different coordinated, 
interdisciplinary projects, in particular New Approaches to Adaptive Water Management under Uncertainty (NeWater) over a period of several years.

Data collection was mainly based on expert judgment obtained through interviews and complemented by document analyses: (1) primary: legal documents, newspaper articles, and governmental reports; and (2) secondary: peer reviewed articles and project reports, which offered deeper insights into certain aspects of management processes in the case studies. In the Tisza case study, one of the interviewed experts verified the mapped representation process with stakeholders from the river basin (Knieper et al. 2010). The time period covered was determined by an estimate of which events needed to be included to reconstruct the development of changes in the flood management paradigm. Then a representation of the historical development in terms of ASs was derived. The resolution in space and time applied to the identification of ASs depended on the research focus of the analyses. The degree of aggregation depended on the overall time period covered by the analysis and the level of detail to be analyzed. For our analyses, quite an aggregated representation was used. Action situations in the case study databases typically covered time periods of several years. Table 2 lists one example of an AS from the early 1970s to 1976: Change Scheldt Estuary Plan with quite complex connections. This AS was of major importance in the reframing of flood management in the Netherlands in which it went from being only a question of safety to also being an issue of ecology. The spatial unit of this AS is the Province of Zeeland, the regional administrative level. The lead actor was at the national level, because the Parliament had to adopt and thus make the final decision on the change to the implementation plan. The AS was, among others, influenced by: the Delta Act, a national regulatory framework; by opposition to closing the Scheldt Estuary; by the Deltawerken, a major national infrastructure program; and by new scientific knowledge on the impacts of closing estuaries. The process, led by the national government, produced a new Scheldt Plan, knowledge about ecosystembased management, knowledge about the ecological value of the Scheldt, and an innovative dam construction for the Scheldt Estuary.

Data were stored in relational databases (Knieper et al. 2010) to support systematic analyses in two ways: (1) to enable visualizations that revealed relationships between spatial levels, phases, and the influence of informal learning for the whole policy process (Inter-AS view, Fig. 2); and (2) to store and structure data about actors and conditions within ASs to allow for qualitative interpretations that are particularly important for the whole process, e.g., viewing intra-AS relations. The three case study databases are accessible online: http://www.newater.uni-osnabrueck.de/index.php?pid=1625.

To support the analyses of the characteristics listed in Table 1 , the identified formal policy and learning processes were represented in an aggregated way as networks of connected ASs (Fig. 2). In addition, Appendix 1 provides (1) a detailed representation of the formal policy and learning processes as networks of connected ASs, in which each individual AS is represented, and all individual phases along the $\mathrm{x}$-axis are resolved (Figs. A1-A3), and (2) a flowchart of ASs in each case study including the influence of major environmental disasters (Figs. A4-A6).

Tables listing the ASs identified for each case study are given in Appendix 1. The tables include the level of an ASs, the lead actor, and the phase in the policy or learning cycle, respectively (Tables A2-A4). Reference to individual ASs during the analyses will be made to the number of an AS in these tables, e.g., HU11, Table A2, refers to AS 11 in the Hungarian case study listed in Table A2. In Appendix 1 tables and figures, ASs referring to learning processes are labeled differently to facilitate cross-comparisons.

\section{RESULTS}

\section{Tisza, Hungary}

After decades of extensive river engineering and regulation, rising trends of flood damage from major floods, despite a shrinking population density in a region of chronic poverty, have increasingly challenged the conventional engineering paradigm (Sendzimir et al. 2007). Slow infiltration of more advanced practices, like polders used as flood volume retention areas, has occurred over recent years. A far more radical and integrated approach has been promoted by an informal network of actors, a so-called shadow network, consisting of representatives from government, academia, and nongovernmental organizations (NGOs; Werners et al. 2009, Sendzimir et al. 2010). Some influence has been exercised by these innovative ideas on the formal policy process. The influence of this shadow network on the evolution of flood policy in the postcommunist period represents the focus of our analysis for this case study.

Figure 3 represents the formal policy and management, the learning processes, and their interdependence. The process comprised essentially the development and implementation of a new flood policy over the past two decades, which led to the new Vasarhelyi Plan (VTT2). The formal policy process shows clear signs of a hierarchical, centralized system dominated by the national level. Strategic goal setting and policy formulation occurred at the national level. Even during implementation, which was located at the subbasin/regional level, actors from the national level took the lead role (see lead actors HU14, HU16, Table A2). Vertical integration, regarding the active involvement of stakeholders from lower levels, in policy development was hardly taking place (see also Tisza case study database, in which the full information is given for the actors and their role in each AS http://www. newater.uni-osnabrueck.de/index.php?pid=1625). 
Fig. 2. Representation of policy and learning processes as sequences or networks of connected action situations (AS). The y-axis represents the spatial level at which an AS is located. The x-axis represents the phases of policy and learning cycles, respectively. To simplify the graphical representation of cases with many ASs and connections between them, ASs in the same phase and the same spatial level are aggregated. The different size of the boxes reflects the number of ASs represented. Furthermore, the seven phases distinguished for the policy cycle in the management and transition framework (MTF; Table A1 in Appendix 1) are aggregated to three major stages.

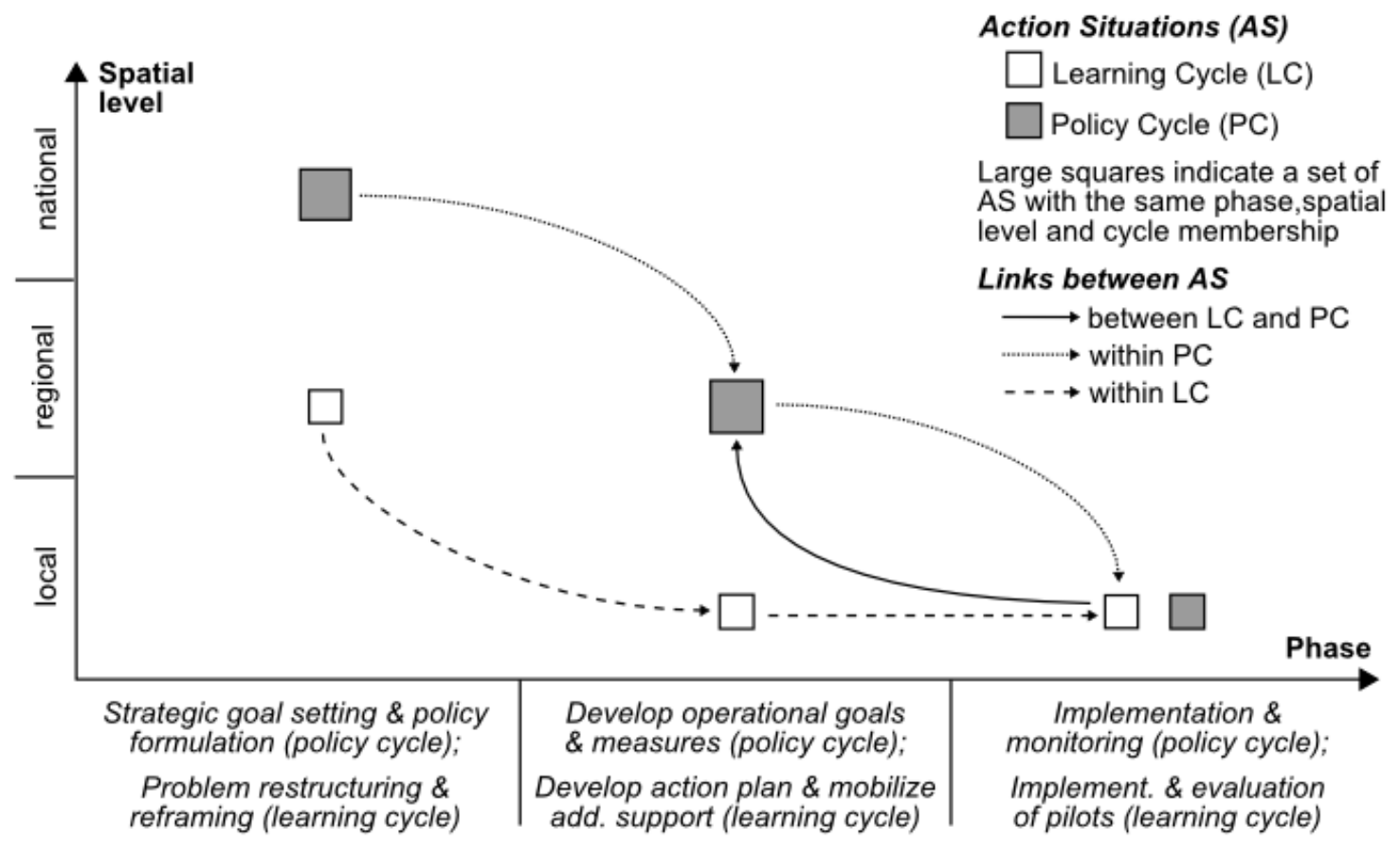

Learning has occurred through a long-term process that consists of a set of connected ASs that evolved in parallel at different levels (L1-L7, Fig. 3). The process embraces all phases of learning from reframing (L1) to developing action plans and mobilizing additional support (L5, L6, L7), and experimental testing (L2, L3, L4).

The learning process is connected to the formal policy process in all phases and at different levels. During the initial reframing stage (L1, Fig.3; HU05, HU06, Table A2), the social learning process influenced policy formulation (HU08, HU09, Table A2) at the national level. A major environmental disaster, a cyanide spill, generated increasing political pressure and increased public awareness for environmental problems (HU06, Table A2). This facilitated the adoption of more ecological considerations, which were generated in a learning process (HU05, Table A2), into flood policy.

Learning at the local and regional levels was mainly linked to bottom-up initiatives, which promoted development and implementation of pilot experiments with floodplain restoration, traditional agriculture, and tourism (L2, L3, Fig.
3 ). These activities played an important role in integration of experiences from other European Union states, traditional knowledge, and innovative approaches from science and produced a set of new insights (HU02, HU03, HU04, Table A2). A remarkable influence from these regional pilot projects to policy formulation at the national level can be noted. Vertical integration regarding feedback from lower levels to strategic national levels was facilitated by nongovernmental actors from the subbasin level taking the lead in the formal policy process at the national level during the policy formulation phase, i.e., the development of the new Vasarhelyi Plan (VTT2; HU13, Table A2). This unusual change in leadership allowed broad participation of regional stakeholders in the policy formulation process. Such regional influence and participation had been unprecedented in this hierarchical, centralized system. Capacity building and knowledge generated in projects funded from international sources (L4, L5, Fig. 3; HU11, HU12, Table A2), insights from experimental pilot projects, the benign political climate, and further severe flooding facilitated the initiation of innovative programs (L6, L7, Fig. 3; HU17, HU18, HU 20, 
Fig. 3. Formal policy and informal learning processes and their interdependencies in the Hungarian Tisza. See Figure 2 for detailed explanations of the notations and Figure A1 in Appendix 1 for the nonaggregated version, in which each individual action situation (AS) and all phases are shown.

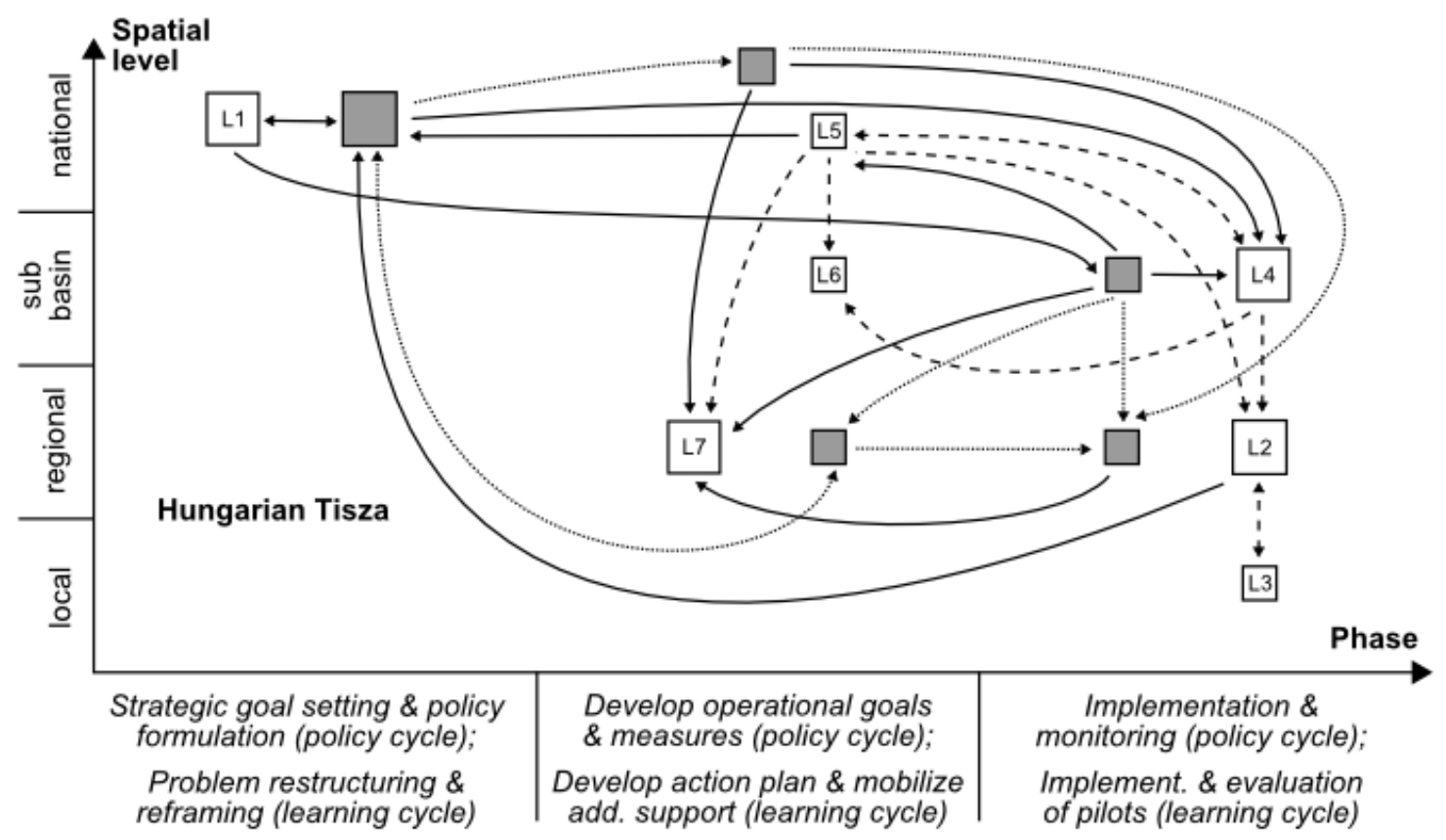

Table A2) and a pilot project as part of the formal implementation process at the regional level (HU14, HU16, Table A2; Fig. A4).

However, the promising initial development toward integrated flood management practices stated in VTT2 seems to have experienced a backlash caused by a weakening influence of the shadow network and the increasing dominance of supporters of a technocratic approach and traditional flood management paradigm in the formal policy process (reinterpretation of VTT2; HU15, Table A2). The influence of the shadow network was never formalized but was triggered by the presence of powerful and charismatic individuals, i.e., Molnar and Varady as shown in Table A2 by their leading roles in many ASs.

\section{Rhine, the Netherlands}

The Netherlands is a country that owes its existence to the success of the drainage of the landscape and the conversion of the sea to inhabitable terrain. Hence an engineering approach and technical control of water flow has been the dominant paradigm for centuries. The disastrous flood of 1953 strengthened the technocratic approach. In the early 1970s, new environmental and democratic discourse arrived, and the negative consequences and risks of large-scale engineering flood defense projects became apparent (Becker et al. 2007, Huitema and Meijerink 2009). The severe floods of the 1990s again caused a reconsideration of flood policy and management practices and a move toward an integrated flood management paradigm. During recent years, a more radical rethinking has taken place, mainly triggered by the prospect of climate change. New policies embrace integrated approaches combining spatial planning and flood management and move toward a landscape management approach that takes into account a wider range of ecosystem services and risks.

Figure 4 represents the formal policy process and instances of learning. The dominance of the national level in shaping policy is indicated by the fact that ASs are predominantly located there. Policy development and implementation of flood management on the coast and at large rivers is a centralized process with a strong leading role at the national level and a strong top-down influence from the national to the regional level. Rijkswaterstaat, a technical governmental organization, has a unique and dominant role in the water expertise community and leads the development of guidelines for water policy, as well as the development of operational goals and measures (see lead role of Rijkswaterstaat in many ASs in Table A3). Through its regional departments, it is also well connected to implementation and thereby ensures effective vertical coordination. Notable are the feedbacks in the formal process from operational and implementation phases to 
strategic goal setting, which indicate that experiences from policy implementation are taken into account in the long-term planning process.

No learning process with its own dynamics, e.g., in which one would expect a sequence of connected learning ASs as in the Hungarian Tisza, has emerged, but several isolated informal learning ASs have been identified. These learning ASs are represented as L1 (NL04, NL17, Table A3) and L2 (NL08, Table A3) in Figure 4. At the regional level, learning was triggered by an opposition to policy plans through what may be called advocacy coalitions (in sensu Sabatier 1998; L1, Fig. 4). Advocacy coalitions refer to diverse groups that are only united for a limited period of time by their opposition to the same governmental plans. This happened in the 1970s with the plan for dike construction in the Scheldt Estuary, in which opposition successfully registered ecological objectives in a revision of initial plans (NL05, Table A3). It happened again 30 years later when opposition successfully blocked plans to flood areas in rural regions, i.e., calamity polders, to protect assets in rich urban settings (Roth and Warner 2007; NL17, Table A3). In both cases, opposition had an influence on the implementation of policy measures at the regional level. The change in planning of the Scheldt Estuary led to innovation in the overall implementation of flood protection measures by taking into account environmental considerations, which had largely been absent before. Such changes in implementation mobilized a learning process at the national level by a heterogeneous group of governmental and nongovernmental actors under the lead of the World Wide Fund For Nature (WWF; L2, Fig.4; NL08, Table A3). They produced the Plan Stork emphasizing a new ecological paradigm for managing floods (Huitema and Meijerink 2009). This plan gained high visibility, but it was only after the 1995 flood that integrated knowledge and ecological considerations were included in an integrated governmental policy (NL15, Table A3). However, the technocratic mode of flood management still surfaced to suppress public involvement. The gravity of this error was only realized later by the protest against the calamity polders. This case exemplifies the growing importance of public participation and has increased awareness for the need to involve stakeholder groups and the public at an early stage in the development and implementation of potentially controversial plans.

\section{Rhine, Germany}

The German Rhine River is highly engineered and regulated, which has resulted in most of the floodplain being lost. Although water quality has improved considerably in the last decades, river morphology is far from natural (Richter and Völker 2010), and flood risk and related damage downstream have increased significantly (Te Linde 2011). The main authority for flood management in Germany lies at the regional level with the federal states, i.e., Bundeslaender. Over the past decades, we have witnessed several shifts in flood management policy: from a purely technocratic approach emphasizing safety and higher dikes toward 'more room for the river,' in combination with ecological considerations to restore floodplains, and in recent years toward the introduction of a precautionary, collaborative flood risk management concept. Although transition has become established as a social construct in societal discourse, a number of issues remain to be tackled to achieve its completion, e.g., a shared, long-term vision for flood management in the Rhine Basin and the political will to take action and collaborate across borders (Becker 2009).

Figure 5 represents the formal policy process and instances of informal learning. Given the autonomy of the regional level, one federal state has been analyzed in more depth: BadenWuerttemberg (BW), one of the states which demonstrated the most concern and it was also the starting point for the water retention projects and the sustainable flood management approach of 'more room for the river.' In the 1982 agreement, France and Germany decided to establish the flood safety standards, i.e., protection against a 200-year flood event, for the Upper Rhine. Baden-Wuerttemberg is obliged to design and plan for water resources and flood management because despite the national German-French treaty, the main actor responsible is the federal state BW (DE03, Table A4). This is also reflected in the direct link (Fig. 5) between strategic goal setting at the international level and operationalization at the regional level by the federal state (DE06, Table A4). This has provided the basis for implementation under the lead of local authorities (DE08, Table A4).

Several isolated ASs at the regional and local levels represent informal learning processes (L1, L2, L3, Fig. 5; DE04, DE05, DE07, Table A4). During the initial phase in the 1980s, learning referred to the generation of knowledge in the expert community (L1, L2). The WWF had a leading role in promoting the foundation of the WWF Floodplain Institute (L1, Fig. 5; DE05, Table A4). It was supported by the government of BW and served as the producer of knowledge on alternative flood protection approaches. The construction of a pilot polder initiated by governmental action and supported by the WWF in BW generated new insights (L2, Fig. 5; DE04, Table A4). New knowledge on ecological aspects of flood management generated by these activities influenced the implementation plans of flood protection measures, which had initially focused on technical aspects only (DE6, DE8, Table A4). Several polders have been planned that combine the development of retention areas with nature restoration (BWME 2007). However, only about $60 \%$ of the planned retention volume could be completed during the nearly 20-year implementation period (IKSR 2007).

Many restoration projects and polder constructions have encountered fierce opposition from local stakeholder advocacy groups, which unite diverse actor groups opposes to 
Fig. 4. Formal policy and informal learning processes and their interdependencies in the Dutch Rhine. See Figure 2 for detailed explanations of the notations and Figure A2 in Appendix 1 for the nonaggregated version.

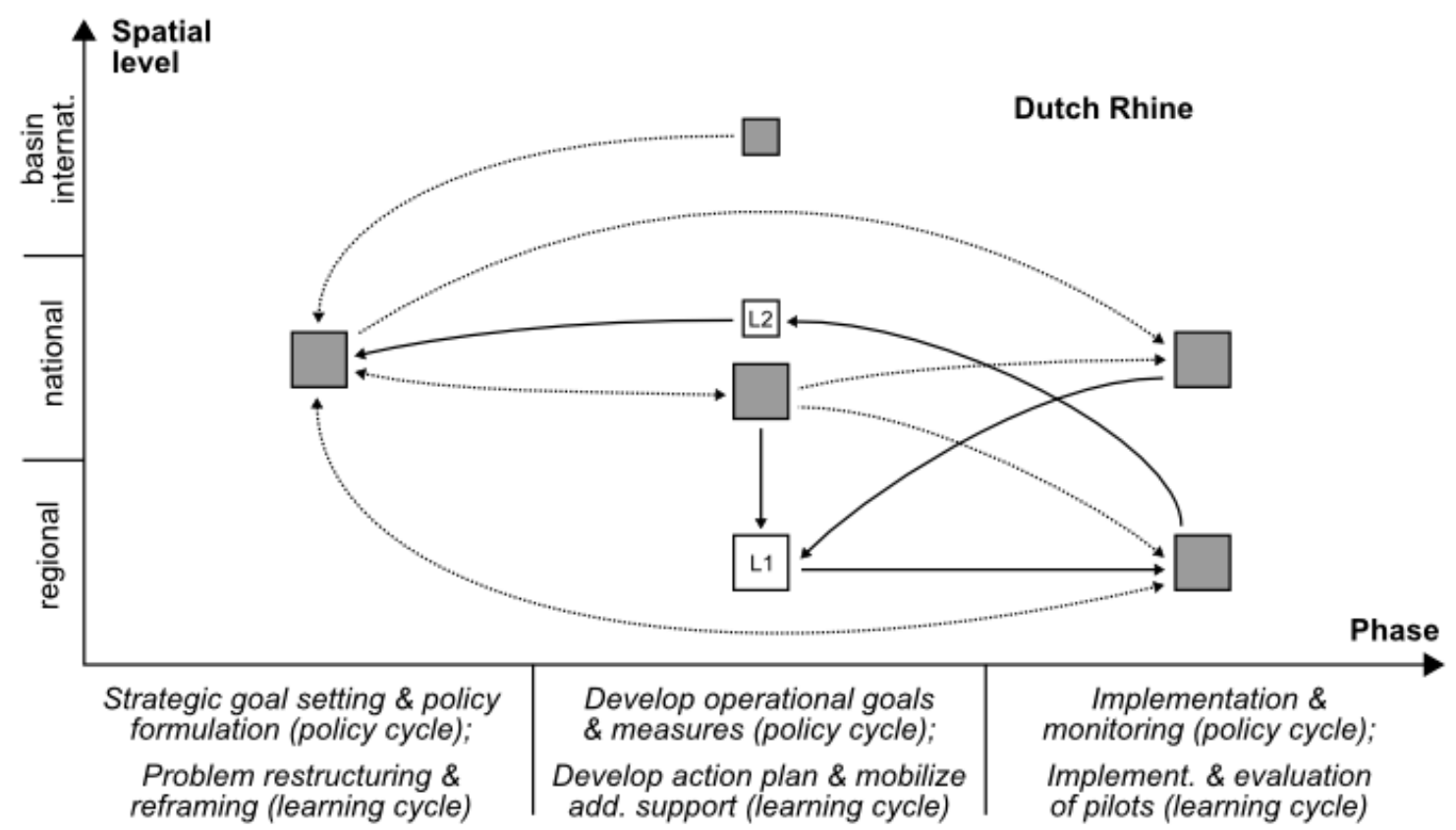

local polder construction for quite different reasons (L3, Fig. 5; DE07, Table A4). Those affected by polder construction were not involved in the early stages of design, but only at the legally prescribed consultation processes of the construction plans in a technocratic top-down approach. Because of failures and several court cases, programs have been started that emphasize public participation and awareness raising at an early stage of operational measures planning (DE9, Table A4).

The consecutive flood events of 1993 and 1995 created the necessary pressure to review flood policies at the national and basin-wide level. At the national level, a guidance paper for German rivers was formalized in 1995 (DE10, Table A4), introducing the precautionary risk concept, summarizing strategies to minimize damage, and emphasizing responsibilities for individual flood protection. At the international level, the Flood Action Plan (FAP) of the International Commission for the Protection of the Rhine (IKSR) was agreed upon in 1998 (DE11, Table A4).

Triggered by the severe Elbe flood in 2002, the German government enacted a national Flood Protection Act. This 2005 first national flood law provided guidance for a more effective coordination among federal states and promoted the precautionary approach emphasizing risk assessment and spatial development (DE12, DE13, Table A4).

\section{COMPARISON OF CASES AND DISCUSSION}

All three cases provided clear evidence that structural change in a flood management paradigm is a long-term process that takes decades rather than years. The analyses of the three cases showed that transformative change is more appropriately described as an evolutionary search process rather than the purposeful design of a new policy. Severe floods provide windows of opportunity because public awareness and political pressure are high during such periods (see role of environmental crises in Figs. A4, A5, A6). Disasters give rise to political and public debate and trigger typically short-term, determined policy responses. But at the same time, they may also support a reframing of policy and reflections on the appropriateness of policy and management approaches, provided that leadership sustains public and professional attention long enough to complete the reformulation process (Sendzimir et al. 2010). Such periods offer opportunities to promote alternative strategies developed in years preceding a disaster, often triggered by earlier extreme events. This happened in all case studies after the severe floods in the 1990s, which provoked the inclusion of integrated approaches and ecological knowledge in policy development and implementation.

Informal settings are important for generating new knowledge and innovative policy approaches. The effectiveness of 
Fig. 5. Formal policy and informal learning processes and their interdependencies in the German Rhine. See Figure 2 for detailed explanations of the notations and Figure A3 in Appendix 2 for the nonaggregated version.

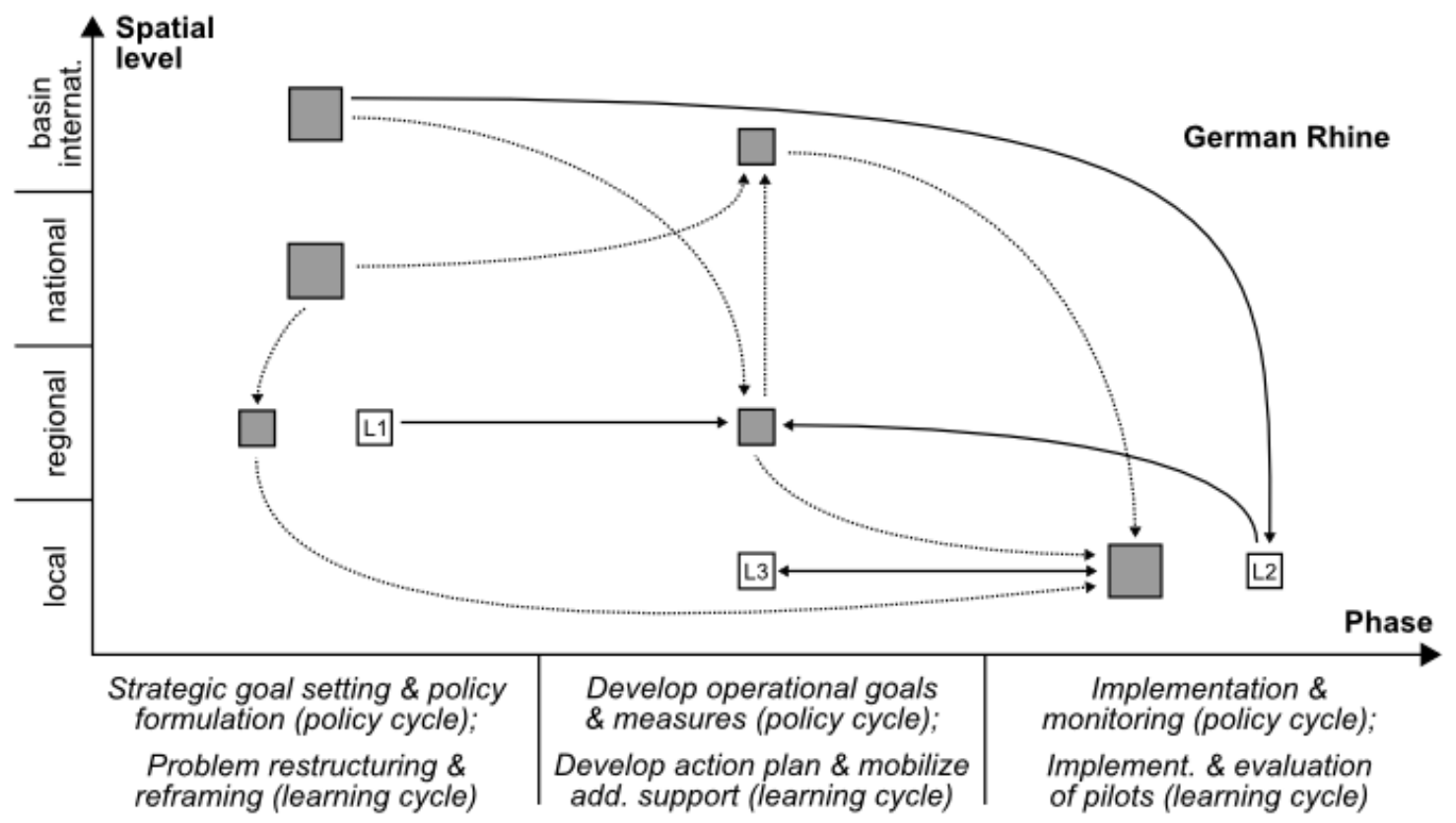

innovation diffusion depends on the links between formal and informal spaces. The three countries show substantial differences in the overall governance structure in this respect (Table 3).

The shadow network in Hungary was effective in integrating different kinds of knowledge and bridging different levels from local to regional to national. It had a strong influence on the policy process during the policy development and implementation phases. However, the role of actors from the shadow network has remained informal, and its influence on the policy process depends on the political climate and contingent factors, such as catastrophes or influential individuals, rather than on more formal and mature contractual relationships. Although the shadow network has effectively used windows of opportunity to influence the formal policy process, it seems not to have been successful in rooting new insights more deeply in the established policy networks of Hungary. It is interesting to note that a similar, largely autonomous bottom-up process could not be identified in the Dutch or the German Rhine basins. It seems that the strength of the informal shadow network in the Hungarian case resulted from the weakness of the government and its absence in bridging levels, e.g., by engaging stakeholders from lower levels in policy development.

Adopting innovative approaches in long-term strategic thinking and supporting their implementation has been pronounced in the Netherlands. This may derive from the fact that the country is the most exposed to flood risk. But it also had the strongest reliance on a technical control paradigm aiming to control floods with a highly sophisticated technical infrastructure. Regarding identified instances of informal learning, clear influence has been exerted on setting strategic goals and during implementation. However, it seems that further informal expert networks are more closely embedded in formal policy (Nooteboom 2006), and these have not been fully captured by the current analysis. Knowledge integration and links to formal policy seem to be quite effective. This might reflect the influence of an expert network that operates across multiple sectors. This network of experts is also indicated by the large number of collaborative actors that could be identified in the policy processes (cf. NL database available online http://www.newater.uni-osnabrueck.de/index.php?pid=1625). These collaborative actors are commissions with representatives from policy, science, and business that are established by government to revisit existing policies, e.g., Delta Commission or Advisory Committee on Water Management for the 21 st century.

Germany and the federal state of Baden-Wuerttemberg, which was explored in greater depth, are less advanced in moving toward an integrated, long-term flood management paradigm than the Netherlands. More advanced approaches within the traditional, i.e., conventional engineering, paradigm have been 
Table 3. Overview of major case study results in comparative perspective.

\begin{tabular}{|c|c|c|c|}
\hline & Tisza, Hungary & Rhine, the Netherlands & Rhine, Germany \\
\hline $\begin{array}{l}\text { Informal learning } \\
\text { process }\end{array}$ & $\begin{array}{l}\text { Driven by informal bottom-up } \\
\text { process, shadow network led by } \\
\text { NGOs developing around shared } \\
\text { mission and new management } \\
\text { paradigm. } \\
\text { Influence on formal policy process in } \\
\text { strategic and operational goal setting } \\
\text { and implementation phases. }\end{array}$ & $\begin{array}{l}\text { Expert communities with actors from } \\
\text { government, NGOs, science, and } \\
\text { business develop alternative } \\
\text { approaches. } \\
\text { Ad hoc Advocacy Coalitions oppose } \\
\text { implementation projects and trigger } \\
\text { policy change. } \\
\text { Influence on formal policy in the } \\
\text { phases of strategic goal setting/policy } \\
\text { formulation and implementation. }\end{array}$ & $\begin{array}{l}\text { Expert communities with actors from } \\
\text { science and government develop } \\
\text { alternative approaches. } \\
\text { Ad hoc Advocacy Coalitions oppose } \\
\text { implementation projects. } \\
\text { Influence on formal policy process in } \\
\text { operational goal setting and } \\
\text { implementation phases. }\end{array}$ \\
\hline $\begin{array}{l}\text { Knowledge } \\
\text { integration in actor } \\
\text { networks } \\
\text { Multilevel } \\
\text { structure and } \\
\text { vertical } \\
\text { coordination }\end{array}$ & $\begin{array}{l}\text { Effective integration of expert and } \\
\text { traditional, local ecological } \\
\text { knowledge in shadow network. } \\
\text { National dominance. } \\
\text { Shadow network effective in bridging } \\
\text { levels - national, regional, local. }\end{array}$ & $\begin{array}{l}\text { Knowledge integration in the expert } \\
\text { community - ecological expert } \\
\text { knowledge. } \\
\text { National dominance. } \\
\text { Key governmental organization } \\
\text { (RWS) links levels. }\end{array}$ & $\begin{array}{l}\text { Knowledge integration in the expert } \\
\text { community - ecological expert } \\
\text { knowledge. } \\
\text { Federal system with autonomy at state } \\
\text { level. National level comparatively } \\
\text { weak. }\end{array}$ \\
\hline $\begin{array}{l}\text { Learning process } \\
\text { outcome - change } \\
\text { in flood } \\
\text { management } \\
\text { paradigm }\end{array}$ & $\begin{array}{l}\text { Discourse advanced and coordinated } \\
\text { by shadow network. } \\
\text { Weak implementation in formal } \\
\text { policy process and management } \\
\text { practice. }\end{array}$ & $\begin{array}{l}\text { Discourse advanced, long-term } \\
\text { strategic planning. } \\
\text { Increasing implementation in formal } \\
\text { policy and management practice. }\end{array}$ & $\begin{array}{l}\text { Discourse emerging but hardly } \\
\text { coordinated across levels or actor } \\
\text { groups. } \\
\text { Long-term considerations only } \\
\text { started. } \\
\text { Partial implementation in policy and } \\
\text { weak coordination in management } \\
\text { practice. }\end{array}$ \\
\hline
\end{tabular}

pursued, in particular during policy implementation, by combining polder construction with ecological considerations and management systems. Learning from local experiences had an influence on policy during the setting of operational goals and implementation. A potential advantage of a federal system with strong autonomy at the state level could be that various federal states could test different approaches and hence promote various innovations in parallel. However, limited knowledge exchange and missing coordination across federal states seem to counteract the potential benefits of such parallel innovation processes.

In both Rhine case studies, the ecological issues in flood protection have been considered and integrated without the trigger of a wider public and stakeholder participation. One reason may be that the integration of new kinds of ecological knowledge is still dominated by an expert-centered approach to planning. Despite the Dutch consensus culture in water policy, wide stakeholder involvement in policy formulation and design of operational measures did not occur. In both the Netherlands and Germany, opposition from groups that had been consulted only at a late stage of the planning process triggered governmental efforts to widen public participation.

More recently, a new European Union directive has pushed toward institutional innovation and Europe-wide coordination in flood management. The European Floods Directive (EFD), which came into force in 2007, supports basin-wide planning in flood management. It gives priority to proactive risk management and flood risk prevention instead of reactive flood protection. An important step was made toward an integrated flood management paradigm by prescribing the coordination of the EFD and the Water Framework Directive (WFD). Systematic analyses and sharing of experiences in flood policy from different countries might be beneficial for effective implementation.

The methodological framework we applied allows the casting of experience from the policy and learning processes of different cases into comparable representations. It draws attention to the multilevel nature of processes, the connection between different levels, and the connection between formal and informal processes and actor networks. Despite standardization, the framework leaves room for different interpretations and emphases. On one hand, this is important to capture the differences between cases. On the other hand, this can be a source for biased representations. Hence comparisons have been exercised with care and focused on what we considered to be robust results and differences detected between the case studies.

\section{CONCLUSIONS}

Major structural transformations are required to facilitate and sustain a paradigm shift toward sustainable resources 
management as advocated by an integrated flood management paradigm. The analyses provide evidence that effective implementation is a multilevel process that cannot be prescribed from the top nor driven from the bottom only. A dynamic balance is required, and over time one or the other direction of influence may dominate. Moving from the discourse on what should be done to the structural transformation depends also on the effectiveness of the links between informal settings and formal policy processes. Informal spaces are important to support the integration of knowledge and experimentation with innovative approaches. Vertical integration is important to involve actors from the implementation level in policy development and to support feedback experiences from implementation to strategic goal setting and policy formulation. In all cases, leadership of individuals or groups proved to be important for fomenting innovative ideas and realizing them in policy change. However, connections between learning and policy processes that hinge on individual actors are fragile if innovative approaches are not codified in formal institutions and widely shared practices.

Environmental considerations seem easier to integrate into a technocratic management approach than participation, which seems to be more threatening to the identity of an expert culture. However, the case studies provided clear evidence that broad participation by a wide range of stakeholder groups and the public at large is required to implement innovative flood management approaches. One cannot expect the public to be supportive of what they do not necessarily understand and which might even be perceived as a threat by some stakeholder groups.

As well, insights gained from case study analyses cast doubts on chances of successful attempts to manage or even steer such transformative processes. Conditions and historical trajectories differ from case to case. The involvement of a wide range of actors is essential, but it generates a dynamic that can hardly be controlled. However, this does not imply that nothing can be done to create enabling conditions for change. Policy development and implementation should experiment more with innovative institutional settings to support links between formal and informal processes, such as local or regional pilot projects to test innovative approaches. To improve the effectiveness of innovation diffusion, the exchange of experiences and learning need to be promoted, which requires improved vertical coordination. Such experimentation should go hand in hand with coordinated efforts in science to develop a comprehensive knowledge base, which would allow general conclusions to be drawn on what is required to facilitate transformative change in different environmental, socioeconomic, cultural, and political settings. To do so, the scientific community needs to improve its methods of mapping the experience of policy experiments into comparable representations and increase collaboration in developing shared databases and large-scale comparative case study analyses.

Responses to this article can be read online at: http://www.ecologyandsociety.org/issues/responses. $\mathrm{php} / 5779$

\section{Acknowledgments:}

We would like to thank Zsuzsanna Flachner, who unfortunately passed away much too early, for her invaluable support in developing the Tisza database. Furthermore, Dave Huitema from the Institute of Environmental Studies at VU University Amsterdam and colleagues from the Institute of Environmental Systems Research at the University of Osnabrueck provided helpful comments during the preparation of this manuscript. The methodological framework of the survey was developed within the scope of the NeWater project, which was financially supported by the European Commission (Contract No. 511179 - NEWATER).

\section{LITERATURE CITED}

Argyris, C., and D. A. Schön. 1978. Organizational learning: a theory of action perspective. Addison-Wesley, Reading, Massachusetts, USA.

Armitage, D. 2008. Governance and the commons in a multilevel world. International Journal of the Commons 2(1):7-32. [online] URL: http://www.thecommonsjournal.org/index. php/ijc/article/viewFile/28/16

Armitage, D., M. Marschke, and R. Plummer. 2008. Adaptive co-management and the paradox of learning. Global Environmental Change 18(1):86-98. http://dx.doi.org/10.1016/ j.gloenvcha.2007.07.002

Baden-Wuerttemberg, Ministry of Environment (BWME). 2007. The integrated Rhine programme. Flood control and restoration of former floodplains along the Upper Rhine. 2nd revised edition. Baden-Wuerttemberg, Ministry of Environment, Stuttgart, Germany. [online] URL: http://www.rp-freiburg.de/ servlet/PB/show/1331108/rpf-ref53.3-kurz-irp-engl.pdf

Bates, B. C., Z. W. Kundzewicz, S. Wu, and J. P. Palutikof, editors. 2008. Climate change and water. Technical paper of the Intergovernmental Panel on Climate Change, IPCC Secretariat, Geneva, Switzerland. [online] URL: http://www. ipcc.ch/pdf/technical-papers/climate-change-water-en.pdf

Becker, G. 2009. Germany: transitions in flood management in the Rhine Basin. Pages 325-348 in D. Huitema and S. Meijerink, editors. Water policy entrepreneurs. A research 
companion to water transitions around the globe. Edward Elgar, Cheltenham, UK. http://dx.doi.org/10.4337/9781849$\underline{803366.00031}$

Becker, G., J. Aerts, and D. Huitema. 2007. Transboundary flood management in the Rhine Basin: challenges for improved cooperation. Water Science and Technology 56 (4):125-135. http://dx.doi.org/ 10.2166/wst.2007.544

Berkes, F., J. Colding, and C. Folke, editors. 2002. Navigating social-ecological systems: building resilience for complexity and change. Cambridge University Press, Cambridge, UK. http://dx.doi.org/10.1017/CBO9780511541957

Dietz, T., E. Ostrom, and P. C. Stern. 2003. The struggle to govern the commons. Science 302:1907-1912. http://dx.doi. org/10.1126/science.1091015

Folke, C., T. Hahn, P. Olsson, and J. Norberg. 2005. Adaptive governance of social-ecological systems. Annual Review of Environment and Resources 30:441-473. http://dx.doi. org/10.1146/annurev.energy.30.050504.144511

Geels, F. W. 2002. Technological transitions as evolutionary reconfiguration processes: a multi-level perspective and a case-study. Research Policy 31(8-9):1257-1274. http://dx.doi. org/10.1016/S0048-7333(02)00062-8

Gleick, P. H. 2003. Global freshwater resources: soft-path solutions for the 21st century. Science 302:1524-1528. http:// dx.doi.org/10.1126/science.1089967

Hargrove, R. 2002. Masterful coaching. Revised edition. Jossey-Bass/Pfeiffer, Hoboken, New Jersey, USA.

Huitema, D., and S. Meijerink. 2009. Policy dynamics in Dutch water management: analyzing the contribution of policy entrepreneurs to policy change. Pages 349-368 in D. Huitema and S. Meijerink, editors. Water policy entrepreneurs. A research companion to water transitions around the globe. Edward Elgar, Cheltenham, UK.

International Commission for the Protection of the Rhine (IKSR). 2007. Umsetzung des aktionsplans hochwasser (Implementation of the flood action plan). Technical Report 156d, International Commission for the Protection of the Rhine, Koblenz, Germany.

Knieper, C., G. Holtz, B. Kastens, and C. Pahl-Wostl. 2010. Analysing water governance in heterogeneous case studies experiences with a database approach. Environmental Science and Policy 13(7):592-603. http://dx.doi.org/10.1016/j. envsci.2010.09.002

Loorbach, D. 2007. Transition management: new mode of governance for sustainable development. International Books, Utrecht, The Netherlands.

Moss, T., and J. Monstadt. 2008. Restoring floodplains in Europe. International Water Association, London, UK.
Nooteboom, S. G. 2006. Adaptive networks. The governance for sustainable development. Dissertation. Erasmus University Rotterdam, Rotterdam, Netherlands.

Olsson, P., L. H. Gunderson, S. R. Carpenter, R. Plummer, L. Lebel, C. Folke, and C. C. Holling. 2006. Shooting the rapids: navigating transitions to adaptive governance of socialecological systems. Ecology and Society 11(1): 18. [online] URL: http://www.ecologyandsociety.org/vol11/iss1/art18/

Opperman, J. J., G. E. Galloway, J. Fargione, J. F. Mount, B. D. Richter, and S. Secchi. 2009. Sustainable floodplains through large-scale reconnection to rivers. Science 326:1487-1488. http://dx.doi.org/10.1126/science.1178256

Ostrom, E. 2001. Vulnerability and polycentric governance systems. International Human Dimensions Programme on Global Environmental Change, Newsletter UPDATE no. 3 (1):3-4.

Ostrom, E. 2005. Understanding institutional diversity. Princeton University Press, Princeton, New Jersey, USA.

Ostrom, E. 2010. Polycentric systems for coping with collective action and global environmental change. Global Environmental Change 20(4):550-557. http://dx.doi.org/10.1016/ j.gloenvcha.2010.07.004

Pahl-Wostl, C. 2007a. Transitions towards adaptive management of water facing climate and global change. Water Resources Management 21(1):49-62. http://dx.doi.org/10.1007/ s11269-006-9040-4

Pahl-Wostl, C. 2007b. The implications of complexity for integrated resources management. Environmental Modelling and Software 22(5):561-569. http://dx.doi.org/10.1016/j. envsoft.2005.12.024

Pahl-Wostl, C. 2009. A conceptual framework for analysing adaptive capacity and multi-level learning processes in resource governance regimes. Global Environmental Change 19(3):354-365. http://dx.doi.org/10.1016/j.gloenvcha.2009.06.001

Pahl-Wostl, C., G. Holtz, B. Kastens, and C. Knieper. 2010. Analyzing complex water governance regimes: the management and transition framework. Environmental Science and Policy 13(7):571-581. http://dx.doi.org/10.1016/ j.envsci.2010.08.006

Pahl-Wostl, C., P. Jeffrey, N. Isendahl, and M. Brugnach. 2011. Maturing the new water management paradigm: progressing from aspiration to practice. Water Resources Management 25(3):837-856. http://dx.doi.org/10.1007/ s11269-010-9729-2

Pahl-Wostl, C., L. Lebel, C. Knieper, and E. Nikitina. 2012. From applying panaceas to mastering complexity: toward adaptive water governance in river basins. Environmental Science and Policy 23:24-34. http://dx.doi.org/10.1016/j. envsci.2012.07.014 
Palmer, M. A., C. A. Reidy Liermann, C. Nilsson, M. Flörke, J. Alcamo, P. S. Lake, and N. Bond. 2008. Climate change and the world's river basins: anticipating management options. Frontiers in Ecology and the Environment 6(2):81-89. http:// dx.doi.org/10.1890/060148

Richter, S., and J. Völker. 2010. Water framework directive: the way towards healthy waters. Results of the German river basin management plans 2009. Federal Ministry for the Environment, Nature Conservation and Nuclear Safety, Berlin, Germany. [online] URL: http://www.umweltbundesamt. de/en/publikationen/water-framework-directive-way-towardshealthy

Roth, D., and J. Warner. 2007. Flood risk, uncertainty and changing river protection policy in the Netherlands: the case of the 'calamity polders.' Tijdschrift voor Economische en Sociale Geografie 98(4):519-525. http://dx.doi.org/10.1111/ j.1467-9663.2007.00419.x

Rotmans, J., R. Kemp, and M. van Asselt. 2001. More evolution than revolution: transition management in public policy. Foresight 3(1):15-31. http://dx.doi.org/10.1108/1463$\underline{6680110803003}$

Sabatier, P. A. 1998. The advocacy coalition framework: revisions and relevance for Europe. Journal of European Public Policy 5(1):98-130. http://dx.doi.org/ 10.1080/13501768880000051

Sendzimir, J., Z. Flachner, C. Pahl-Wostl, and C. Knieper. 2010. Stalled regime transition in the upper Tisza River Basin: the dynamics of linked action situations. Environmental Science and Policy 13(7):604-619. http://dx.doi.org/10.1016/ j.envsci.2010.09.005

Sendzimir, J., P. Magnuszewski, Z. Flachner, P. Balogh, G. Molnar, A. Sarvari, and Z. Nagy. 2007. Assessing the resilience of a river management regime: informal learning in a shadow network in the Tisza River Basin. Ecology and Society 13(1): 11. [online] URL: http://www.ecologyandsociety. org/vol13/iss1/art11/

Smith, M., and S. Barchiesi. 2009. Environment as infrastructure - resilience to climate change impacts on water through investments in nature. Water Programme, International Union for Conservation of Nature (IUCN), Gland, Switzerland. [online] URL: http://cmsdata.iucn.org/ downloads/iucn_environment_as infrastructure_1.pdf

Smith, A., and A. Stirling. 2010. The politics of socialecological resilience and sustainable socio-technical transitions. Ecology and Society 15(1): 11. [online] URL: http://www.ecologyandsociety.org/vol15/iss1/art11/

Smith, A., A. Stirling, and F. Berkhout. 2005. The governance of sustainable socio-technical transitions. Research Policy 34 (10):1491-1510. http://dx.doi.org/10.1016/j.respol.2005.07.005
Te Linde, A. H. 2011. Rhine at risk? Impact of climate change on low-probability floods in the Rhine Basin and the effectiveness offlood managementmeasures. Dissertation. VU University Amsterdam, Amsterdam, Netherlands.

Vörösmarty, C. J., P. B. McIntyre, M. O. Gessner, D. Dudgeon, A. Prusevich, P. Green, S. Glidden, S. E. Bunn, C. A. Sullivan, C. Reidy Liermann, and P. M. Davies. 2010. Global threats to human water security and river biodiversity. Nature 467:555-561. http://dx.doi.org/10.1038/nature09440

Werners, S. E., P. Matczak, and Z. Flachner. 2009. The introduction of floodplain rehabilitation and rural development into the water policy for the Tisza River in Hungary. Pages 250-271 in D. Huitema and S. Meijerink, editors. Water policy entrepreneurs. A research companion to water transitions around the globe. Edward Elgar, Cheltenham, UK. http://dx.doi.org/10.4337/9781849803366.00027

White, G. F. 1945. Human adjustment to floods. Department of Geography Research Paper no. 29. University of Chicago, Chicago, Illinois, USA.

World Meteorological Organization (WMO). 2009. Integrated flood management concept paper. World Meteorological Organization, Geneva, Switzerland. [online] URL: http://www.apfm.info/publications//concept_paper_e. pdf 
APPENDIX

Supplementary Information

for

How multi-level societal learning processes facilitate transformative change: A comparative case study analysis on flood management

Ecology and Society 


\section{Supplementary Figures}

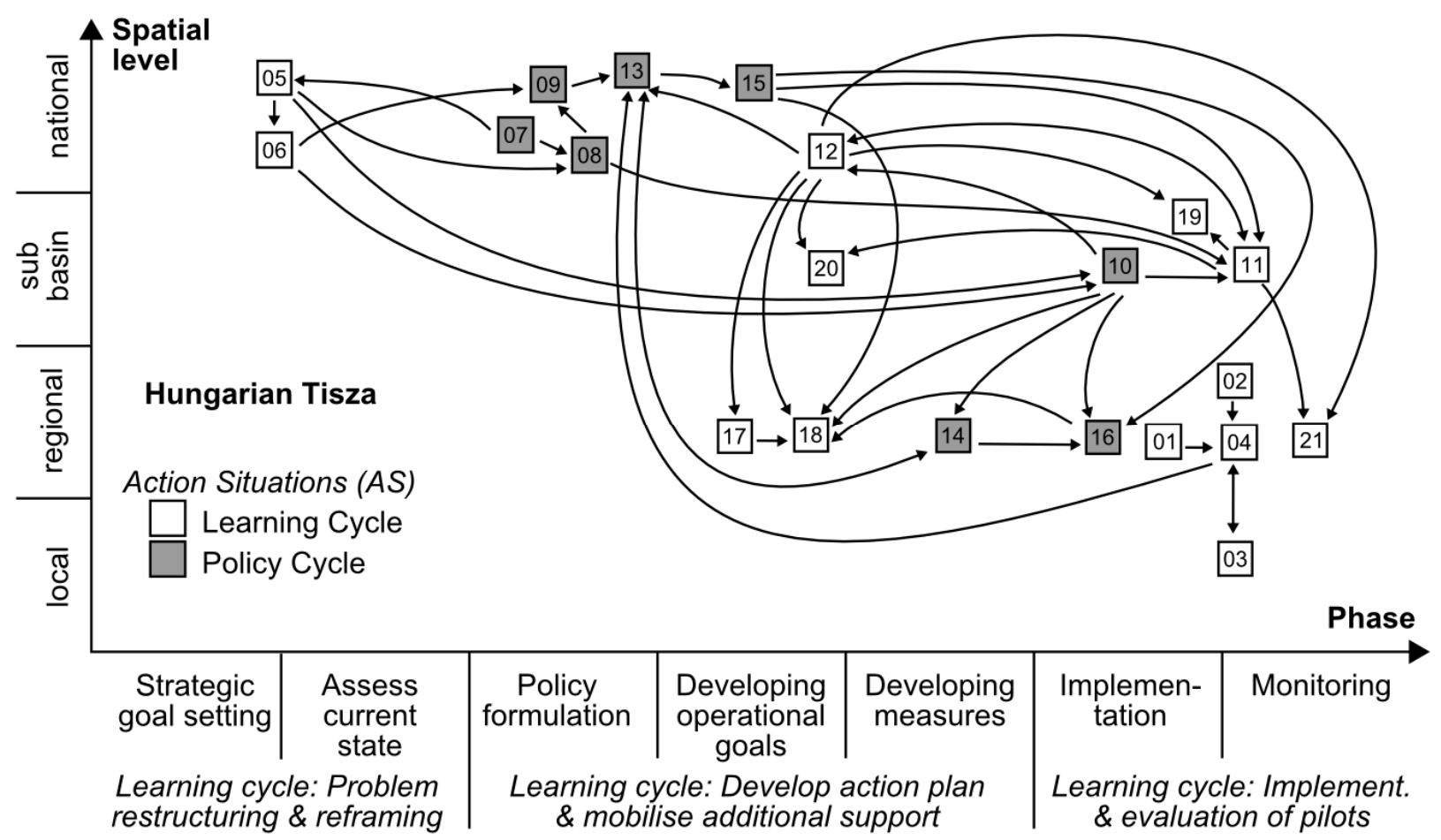

Figure A1. Formal policy and informal learning processes and their interdependencies in the Hungarian Tisza. Non-aggregated version of Fig. 3. The numbers refer to the ASs as listed in Table A2. 


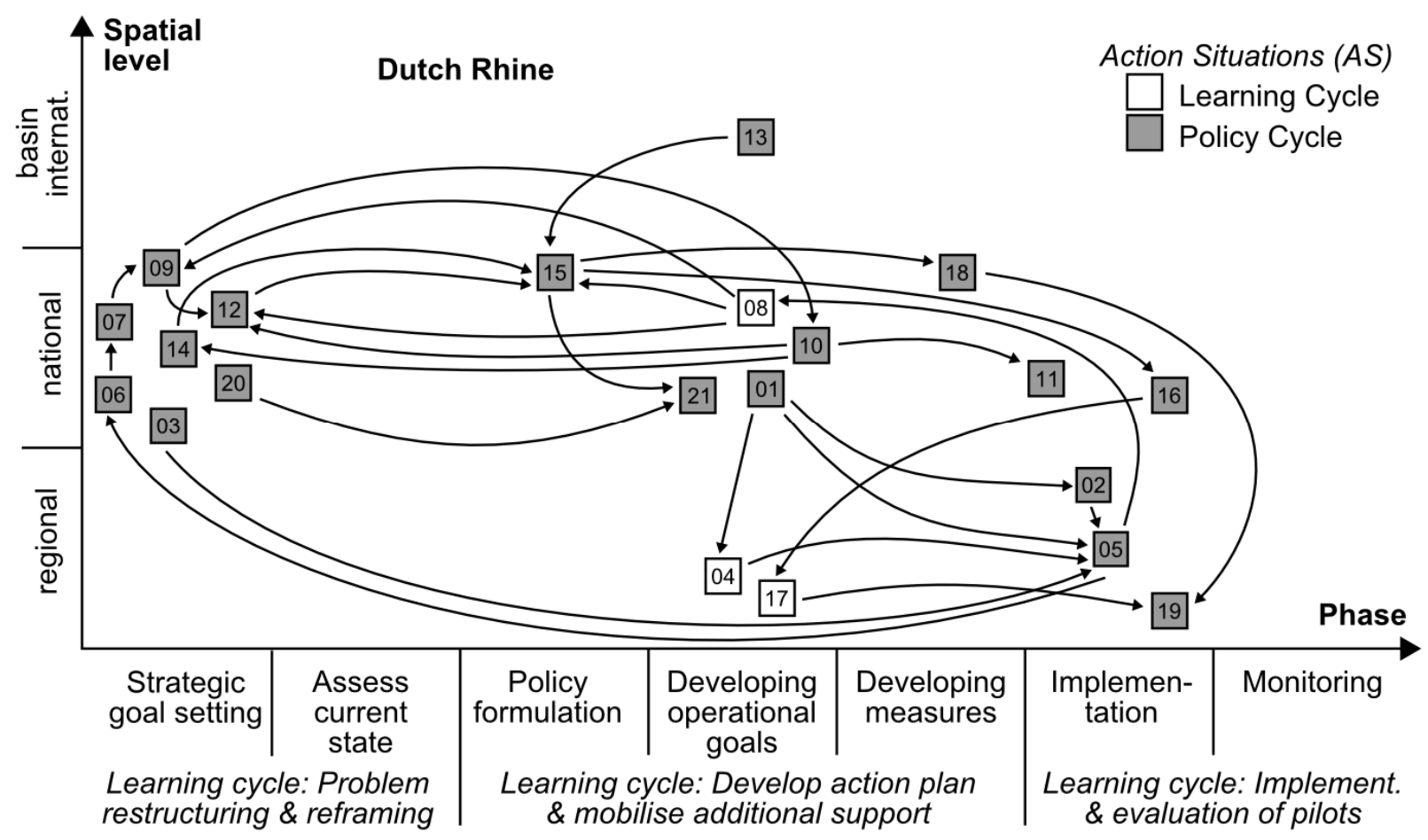

Figure A2. Formal policy and informal learning processes and their interdependencies in the Dutch Rhine. Non-aggregated version of Fig. 4. The numbers refer to the ASs as listed in Table A3.

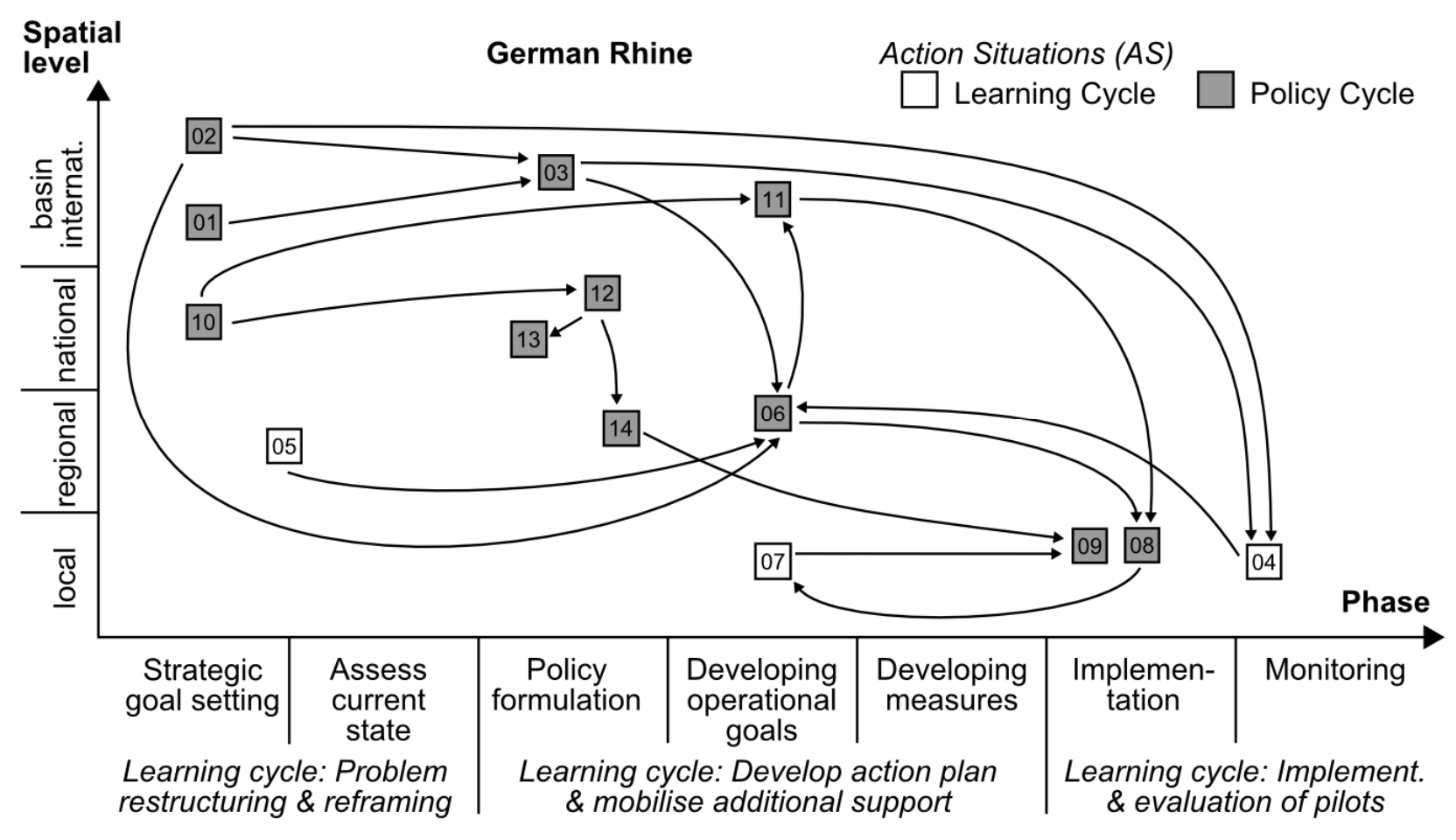

Figure A3. Formal policy and informal learning processes and their interdependencies in the German Rhine. Non-aggregated version of Fig. 5. The numbers refer to the ASs as listed in Table A4. 


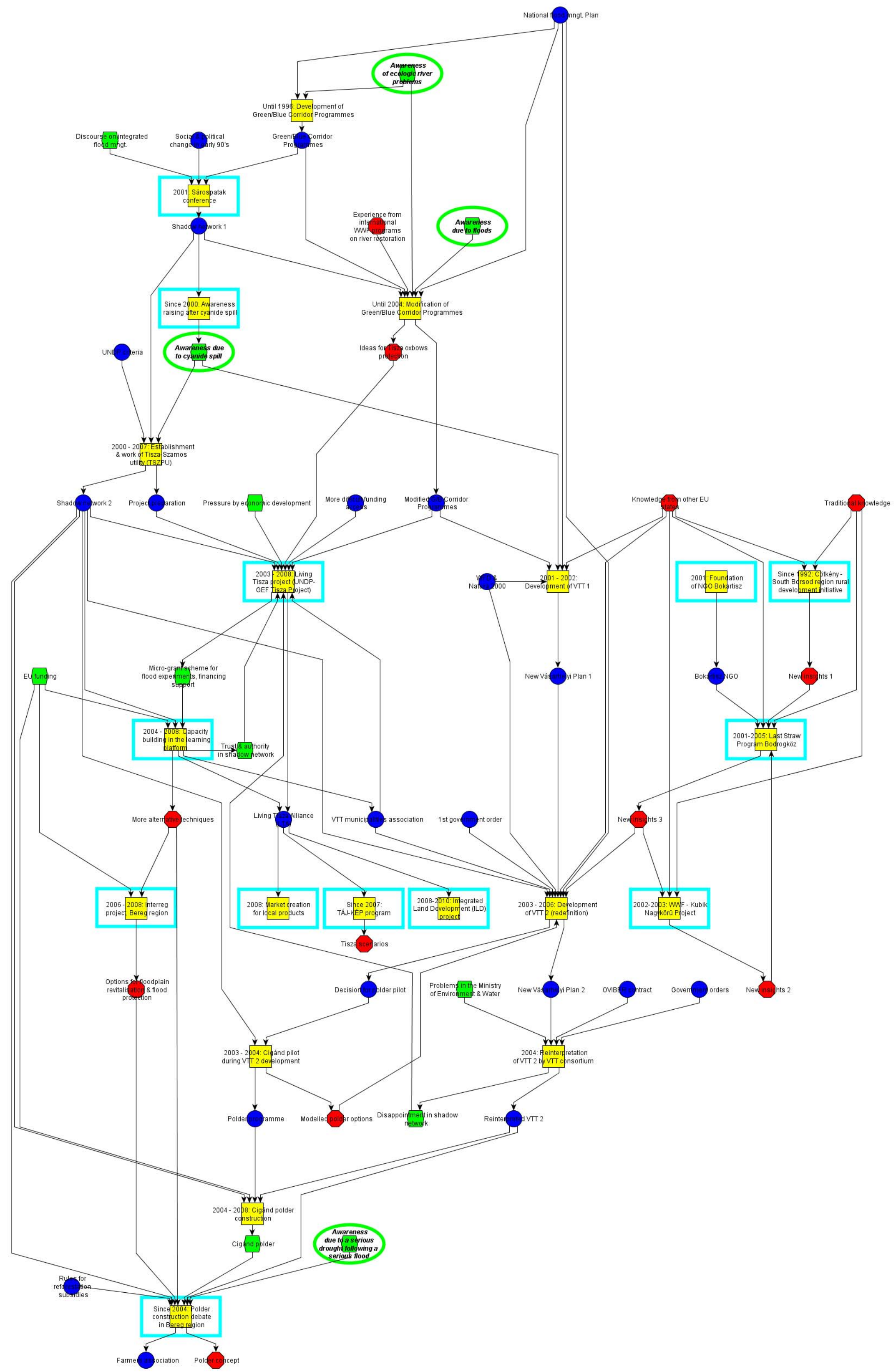

Figure A4. Tisza: Network of action situations (ASs) linked by institutions (blue circle), knowledge (red octagon) or operational outcomes (green hexagon). Learning AS are marked by a turquois rectangle. Extreme events and their impacts on public perception and policy response are marked by a green oval. 


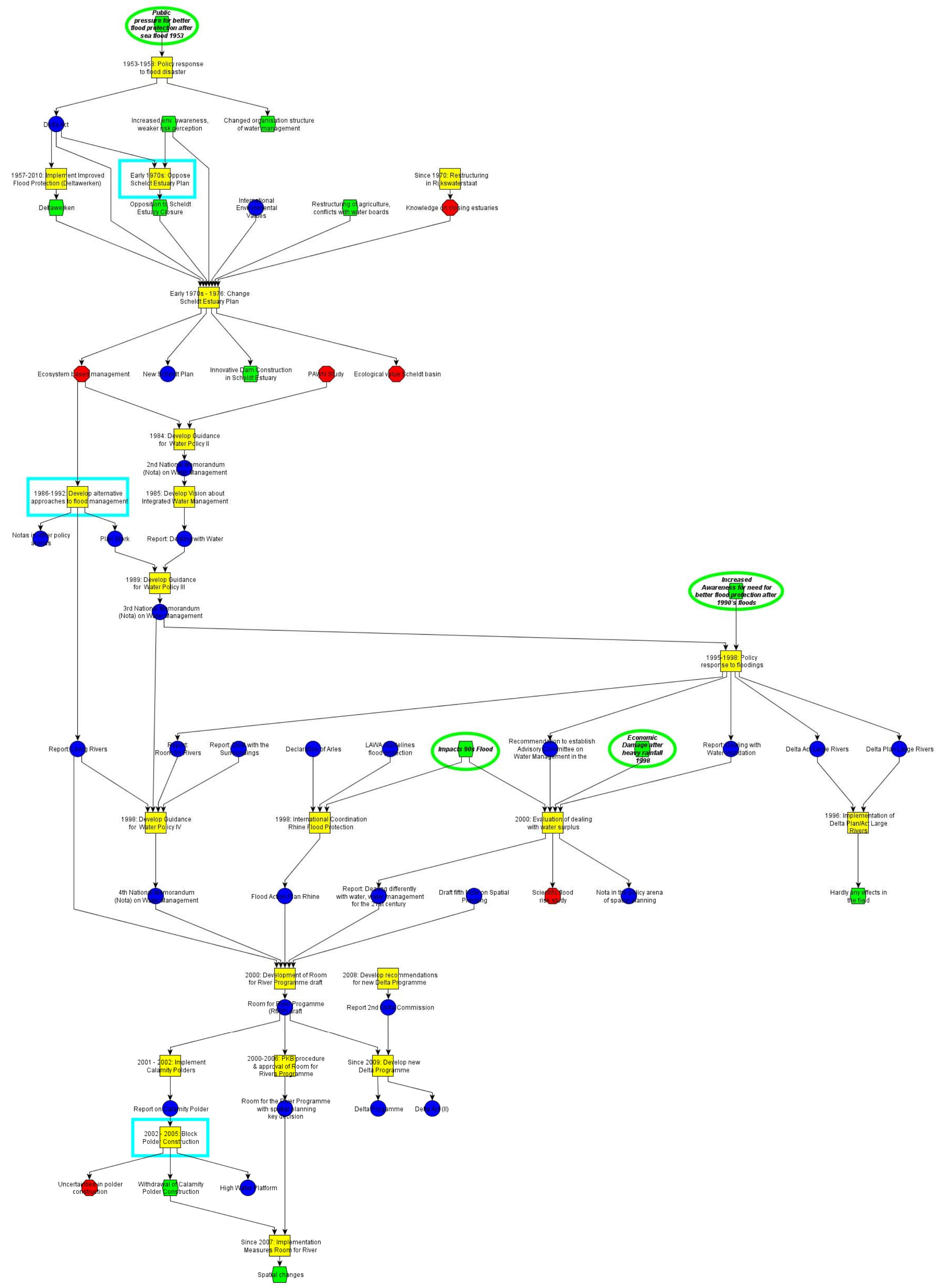

Figure A5. Rhine Netherlands: Network of action situations (ASs) linked by institutions (blue circle), knowledge (red octagon) or operational outcomes (green hexagon). Learning AS are marked by a turquois rectangle. Extreme events and their impacts on public perception and policy response are marked by a green oval. 


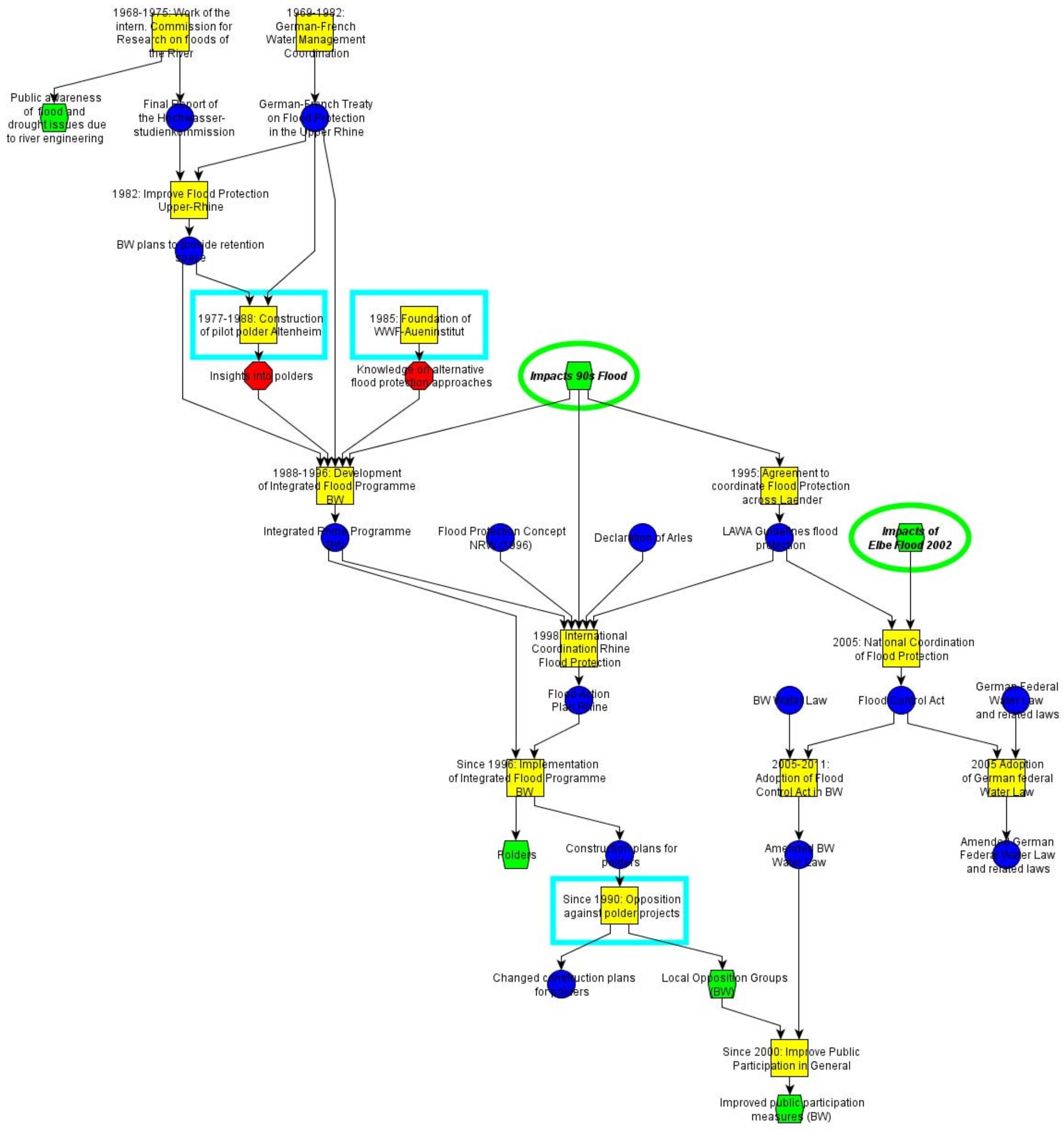

Figure A6. Rhine Germany: Network of action situations (ASs) linked by institutions (blue ball), knowledge (red octagon) or operational outcomes (green hexagon). Learning AS are marked by a turquois rectangle. Extreme events and their impacts on public perception and policy response are marked by a green oval. 


\section{Supplementary Tables}

Table A1. Definition of terms used for the Management and Transition Framework (MTF) analyses in this paper (cf. Pahl-Wostl et al, 2010).

\begin{tabular}{|c|c|c|}
\hline MTF Term & Explanation & Attributes Used in the Analyses \\
\hline $\begin{array}{l}\text { Action Situation } \\
\text { (AS) }\end{array}$ & $\begin{array}{l}\text { Structured social interaction context } \\
\text { that leads to specific outcomes. }\end{array}$ & $\begin{array}{l}\text { Spatial Unit (cf. below) } \\
\text { Phase (cf. below) }\end{array}$ \\
\hline Actor & $\begin{array}{l}\text { Individual or collective participant } \\
\text { populating an 'action arena' and taking } \\
\text { part in AS with certain 'roles. }\end{array}$ & $\begin{array}{l}\text { Spatial Unit (cf. below) } \\
\text { Individual, collective, collaborative }\end{array}$ \\
\hline Spatial Unit & & $\begin{array}{l}\text { National, regional } \\
\text { International, national basin, sub-basin }\end{array}$ \\
\hline $\begin{array}{l}\text { Phase Policy } \\
\text { Process }\end{array}$ & $\begin{array}{l}\text { Stylized phased of formal policy } \\
\text { processes }\end{array}$ & $\begin{array}{l}\text { - } \text { Strategic goal setting } \\
\text { - } \text { Assess current state } \\
\text { - } \text { Policy formation } \\
\text { - } \quad \text { Developing operational goals } \\
\text { - } \text { Developing measures } \\
\text { - Implementation } \\
\text { - } \quad \text { Monitoring }\end{array}$ \\
\hline Phase Learning & $\begin{array}{l}\text { Stylized phases of largely informal } \\
\text { learning processes }\end{array}$ & $\begin{array}{l}\text { - Problem structuring and } \\
\text { reframing } \\
\text { - Develop action plan and } \\
\text { mobilise additional support } \\
\text { - Implementation and evaluation } \\
\text { of pilots/experiments }\end{array}$ \\
\hline Role & $\begin{array}{l}\text { A 'role' is held by an 'actor' during an } \\
\text { AS. Roles belong thus to the relation } \\
\text { 'actor' - AS and not to the 'actor' }\end{array}$ & $\begin{array}{l}\text { Lead } \\
\text { Active participant } \\
\text { Passive participant }\end{array}$ \\
\hline Institution & $\begin{array}{l}\text { Institution refers to a set of rules, } \\
\text { decision-making procedures, programs } \\
\text { that define social practices, assign roles } \\
\text { to the participants in these practices, } \\
\text { and guide interactions among the } \\
\text { occupants of individual roles. }\end{array}$ & Formal or informal \\
\hline Knowledge & $\begin{array}{l}\text { Knowledge refers to meaningful } \\
\text { information and experience. }\end{array}$ & \\
\hline $\begin{array}{l}\text { Operational } \\
\text { Outcome }\end{array}$ & $\begin{array}{l}\text { Operational Outcomes are concrete } \\
\text { measurable effects of water } \\
\text { management. Examples are technical or } \\
\text { infrastructural actions (e.g. construction } \\
\text { of dykes), improvements of water } \\
\text { quality, increased public awareness. }\end{array}$ & \\
\hline
\end{tabular}


Table A2. Action Situations for the Tisza Hungary (HU, learning ASs in pink).

\begin{tabular}{|c|c|c|c|c|c|}
\hline No. & Name Action Situation & Spatial Unit & $\begin{array}{l}\text { Admin. } \\
\text { Level }\end{array}$ & Lead Actor & Phase \\
\hline HU02 & $\begin{array}{l}\text { Since 1992: Cötkény - South } \\
\text { Borsod region rural development } \\
\text { initiative }\end{array}$ & South Borsod & Regional & Cötkény (A. Sárvári) & $\begin{array}{l}\text { Learning Cycle - Implementation and } \\
\text { Evaluation of Pilots/Experiments }\end{array}$ \\
\hline HU03 & $\begin{array}{l}\text { 2002-2003: World Wide Fund } \\
\text { For Nature (WWF) - Kubik } \\
\text { Nagykörü Project }\end{array}$ & $\begin{array}{l}\text { Municipality of } \\
\text { Nagykörü }\end{array}$ & Local & WWF Hungary NGO (L. Haraszthy) & $\begin{array}{l}\text { Learning Cycle - Implementation and } \\
\text { Evaluation of Pilots/Experiments }\end{array}$ \\
\hline HU04 & $\begin{array}{l}\text { 2001-2005: Last Straw Program } \\
\text { Bodrogköz }\end{array}$ & $\begin{array}{l}\text { Bodrog/Bodrogköz } \\
\text { region }\end{array}$ & Regional & Mr. G. Molnár & $\begin{array}{l}\text { Learning Cycle - Implementation and } \\
\text { Evaluation of Pilots/Experiments }\end{array}$ \\
\hline HU05 & 2001: Sárospatak conference & Hungary & National & Bokartisz NGO (G. Molnár) & $\begin{array}{l}\text { Learning Cycle - Problem Structuring } \\
\text { and Reframing }\end{array}$ \\
\hline HU06 & $\begin{array}{l}\text { Since 2000: Awareness raising } \\
\text { after cyanide spill }\end{array}$ & Hungary & National & $\begin{array}{l}\text { Hungarian Ministry of Environment \& } \\
\text { Water (J. Váradi) }\end{array}$ & $\begin{array}{l}\text { Learning Cycle - Problem Structuring } \\
\text { and Reframing }\end{array}$ \\
\hline HU09 & $\begin{array}{l}2001 \text { - 2002: Development of } \\
\text { New Vásarhelyi Plan (VTT) } 1\end{array}$ & Hungary & National & $\begin{array}{l}\text { Hungarian Ministry of Environment \& } \\
\text { Water (J. Váradi) }\end{array}$ & Policy Formulation \\
\hline HU10 & $\begin{array}{l}2000 \text { - 2007: Establishment \& } \\
\text { work of Tisza-Szamos utility }\end{array}$ & $\begin{array}{l}\text { Tisza river \& } \\
\text { Szamos tributary }\end{array}$ & Sub-Basin & $\begin{array}{l}\text { Hungarian Ministry of Environment \& } \\
\text { Water (J. Váradi) }\end{array}$ & Implementation \\
\hline HU11 & $\begin{array}{l}2003 \text { - 2008: Living Tisza project } \\
\text { (UNDP-GEF Tisza Project) }\end{array}$ & Hungarian Tisza & Sub-Basin & Mr. P. Kajner & $\begin{array}{l}\text { Learning Cycle - Implementation and } \\
\text { Evaluation of Pilots/Experiments }\end{array}$ \\
\hline HU12 & $\begin{array}{l}2004 \text { - 2008: Capacity building in } \\
\text { the learning platform }\end{array}$ & Hungary & National & NeWater project & $\begin{array}{l}\text { Learning Cycle - Develop Action Plan } \\
\text { and Mobilise Additional Support }\end{array}$ \\
\hline HU13 & $\begin{array}{l}2003 \text { - 2006: Development of } \\
\text { VTT } 2 \text { (redefinition) }\end{array}$ & Hungary & National & Bokartisz NGO (G. Molnár) & Policy Formulation \\
\hline
\end{tabular}




\begin{tabular}{llllll}
\hline \hline HU14 & $\begin{array}{l}\text { 2003 - 2004: Cigánd pilot during } \\
\text { VTT 2 development }\end{array}$ & $\begin{array}{l}\text { Bodrog/Bodrogköz } \\
\text { region }\end{array}$ & Regional & $\begin{array}{l}\text { National government, interministerial } \\
\text { committee }\end{array}$ & Developing Measures \\
\hline HU15 & $\begin{array}{l}\text { 2004: Reinterpretation of VTT } 2 \\
\text { by VTT consortium }\end{array}$ & Hungary & National & $\begin{array}{l}\text { VTT consortium (lead: National Water } \\
\text { Management Investment Projects } \\
\text { Company (OVIBER)) }\end{array}$ & Developing Operational Goals \\
\hline HU16 & $\begin{array}{l}\text { 2004 - 2008: Cigánd polder } \\
\text { construction }\end{array}$ & $\begin{array}{l}\text { Bodrog/Bodrogköz } \\
\text { region }\end{array}$ & Regional & OVIBER & Implementation \\
\hline HU17 & $\begin{array}{l}\text { 2006 - 2008: Interreg project, } \\
\text { Bereg region }\end{array}$ & Bereg region & Regional & $\begin{array}{l}\text { Upper Tisza Regional Water Directorate } \\
\text { FETIKÖVIZIG (Bodnár G.) }\end{array}$ & $\begin{array}{l}\text { Learning Cycle - Develop Action Plan } \\
\text { and Mobilise Additional Support }\end{array}$ \\
\hline HU18 & $\begin{array}{l}\text { Since 2004: Polder construction } \\
\text { debate in Bereg region }\end{array}$ & Bereg region & Regional & Shadow network 2 & $\begin{array}{l}\text { Learning Cycle - Develop Action Plan } \\
\text { and Mobilise Additional Support }\end{array}$ \\
\hline HU19 & $\begin{array}{l}\text { 2008-2010: Integrated Land } \\
\text { Development project }\end{array}$ & $\begin{array}{l}\text { Tisza basin In } \\
\text { Hungary, Romania } \\
\text { \& Serbia }\end{array}$ & Sub-Basin & $\begin{array}{l}\text { International Commission for the } \\
\text { Protection of the Danube River }\end{array}$ & $\begin{array}{l}\text { Learning Cycle - Implementation and } \\
\text { Evaluation of Pilots/Experiments }\end{array}$ \\
\hline HU20 & $\begin{array}{l}\text { Since 2007: TÁJ-KÉP program } \\
\text { Hungarian Tisza }\end{array}$ & Sub-Basin & $\begin{array}{l}\text { Research Institute for Soil Science and } \\
\text { Agricultural Chemistry }\end{array}$ & $\begin{array}{l}\text { Learning Cycle - Develop Action Plan } \\
\text { and Mobilise Additional Support }\end{array}$ \\
\hline HU21 & $\begin{array}{l}\text { 2008: Market creation for local } \\
\text { products }\end{array}$ & $\begin{array}{l}\text { Western Hungary } \\
\text { (Hungarian Tisza } \\
\text { basin \& Budapest) }\end{array}$ & Regional & Institutionalised Living Tisza Alliance & $\begin{array}{l}\text { Learning Cycle - Implementation and } \\
\text { Evaluation of Pilots/Experiments }\end{array}$ \\
\hline
\end{tabular}


Table A3. Action Situations for Rhine Netherlands (NL, learning ASs in pink).

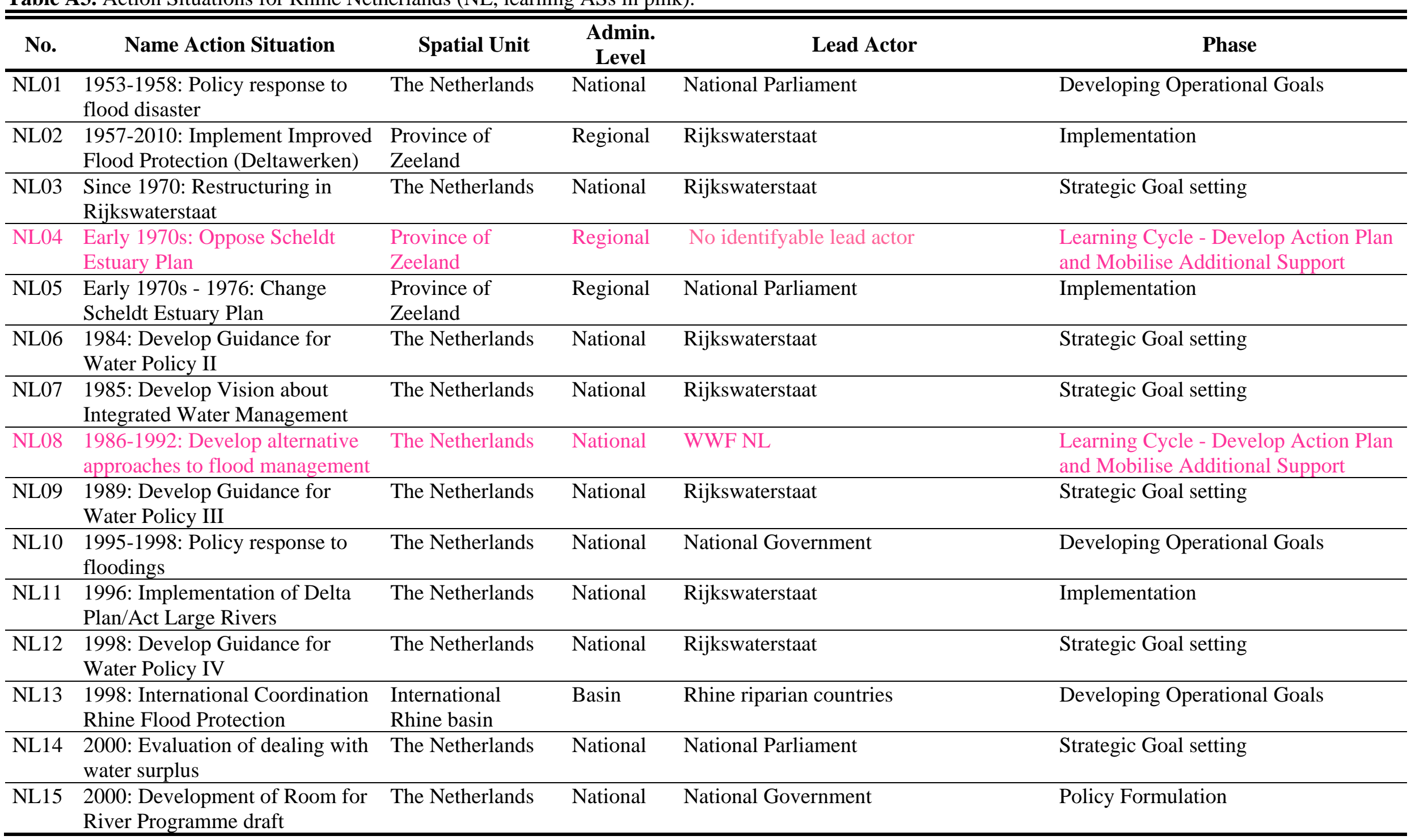




\begin{tabular}{llllll}
\hline \hline NL16 & $\begin{array}{l}\text { 2001 - 2002: Implement } \\
\text { Calamity Polders }\end{array}$ & The Netherlands & National & $\begin{array}{l}\text { State secretary M. de Vries for Transport, Implementation } \\
\text { Public Works, and Water Management, } \\
\text { New state secretary Schultz-van Hagen } \\
\text { for Transport, Public Works, and Water } \\
\text { Management }\end{array}$ \\
\hline NL17 & $\begin{array}{l}\text { 2002 - 2005: Block Polder } \\
\text { Construction }\end{array}$ & $\begin{array}{l}\text { Area in the } \\
\text { Gelderland } \\
\text { Province }\end{array}$ & Regional & $\begin{array}{l}\text { Hoogwaterplatform Ooijpolder Dueffelt } \\
\text { NLearning Cycle - Develop Action Plan } \\
\text { and Mobilise Additional Support }\end{array}$ \\
\hline $\begin{array}{l}\text { 2000-2006: PKB procedure \& } \\
\text { approval of Room for Rivers } \\
\text { Programme }\end{array}$ & The Netherlands & National & National Parliament & Developing Measures \\
\hline $\begin{array}{l}\text { NL19 } \\
\text { Measures Room for River }\end{array}$ & $\begin{array}{l}\text { The Netherlands } \\
\text { (regional) }\end{array}$ & Regional & Rijkswaterstaat & Implementation \\
\hline $\begin{array}{l}\text { No08: Develop recommendations } \\
\text { for new Delta Programme }\end{array}$ & $\begin{array}{l}\text { The Netherlands } \\
\text { Programme }\end{array}$ & National & National Government & Strategic Goal setting \\
\hline NL21 & $\begin{array}{l}\text { Since 2009: Develop new Delta } \\
\text { The Netherlands }\end{array}$ & National & National Parliament & $\begin{array}{l}\text { Strategic Goal setting, } \\
\text { Developing Operational Goals }\end{array}$ \\
\hline
\end{tabular}


Table A4. Action Situations for the Rhine Germany (DE, learning ASs in pink).

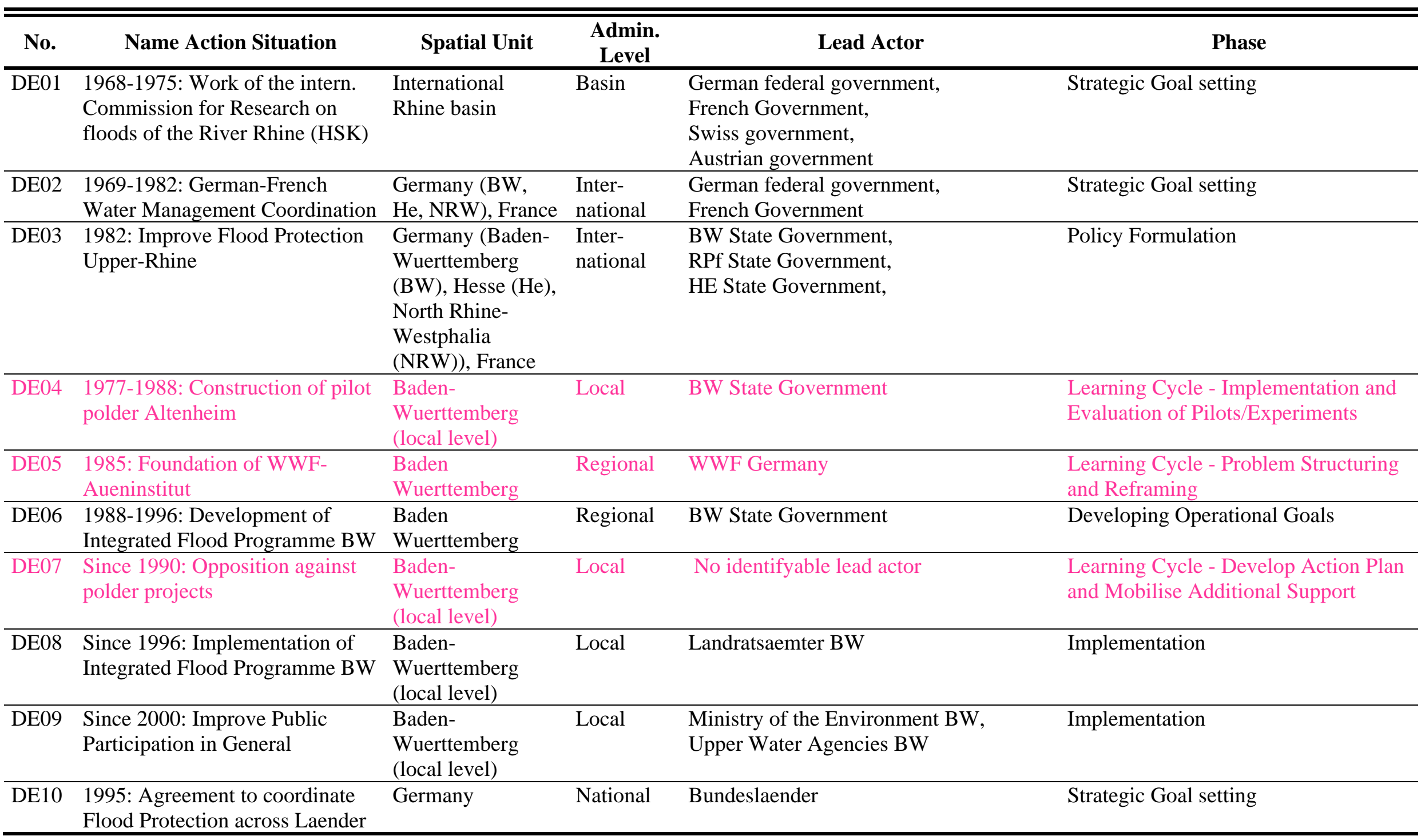




\begin{tabular}{llllll}
\hline \hline DE11 & $\begin{array}{l}\text { 1998: International Coordination } \\
\text { Rhine Flood Protection }\end{array}$ & $\begin{array}{l}\text { International } \\
\text { Rhine basin }\end{array}$ & Basin & $\begin{array}{l}\text { Rhine Minister Conference, } \\
\text { NL Delegation, } \\
\text { Switzerland (CH) Delegation, } \\
\text { DE Delegation }\end{array}$ & Developing Operational Goals \\
\hline DE12 & $\begin{array}{l}\text { 2005: National Coordination of } \\
\text { Flood Protection }\end{array}$ & Germany & National & $\begin{array}{l}\text { Bundeslaender, } \\
\text { German federal government, } \\
\text { Bundestag }\end{array}$ & Policy Formulation \\
\hline DE13 & $\begin{array}{l}\text { 2005: Adoption of German } \\
\text { federal Water Law }\end{array}$ & Germany & National & $\begin{array}{l}\text { German Ministry of Transport, Building } \\
\text { and Urban Development, } \\
\text { German Ministry of the Environment, } \\
\text { German Ministry of the Economy }\end{array}$ & Policy Formulation \\
& & & Ministry of the Environment BW & Policy Formulation \\
\hline DE14 & $\begin{array}{l}\text { 2005-2011: Adoption of Flood } \\
\text { Control Act in BW }\end{array}$ & $\begin{array}{l}\text { Baden } \\
\text { Wuerttemberg }\end{array}$ & Regional & & \\
\hline
\end{tabular}

\section{Case Study Databases}

Case study databases for the three case studies can be downloaded on the following website: http://www.newater.uni-osnabrueck.de/index.php?pid=1625 